\title{
Microbiological processes in banded iron formation deposition
}

\author{
NICOLE R. POSTH*1, KURT O. KONHAUSER† and ANDREAS KAPPLER* \\ *Center for Applied Geosciences, University of Tuebingen, 72076, Tuebingen, Germany \\ (E-mail: andreas.kappler@uni-tuebingen.de) \\ $\dagger$ Department of Earth and Atmospheric Sciences, University of Alberta, Edmonton, Alberta, Canada \\ T6G $2 E 3$
}

\begin{abstract}
Banded iron formations have been studied for decades, particularly regarding their potential as archives of the Precambrian environment. In spite of this effort, the mechanism of their deposition and, specifically, the role that microbes played in the precipitation of banded iron formation minerals, remains unresolved. Evidence of an anoxic Earth with only localized oxic areas until the Great Oxidation Event $c a 2.45$ to 2.32 Ga makes the investigation of $\mathrm{O}_{2}$-independent mechanisms for banded iron formation deposition relevant. Recent studies have explored the long-standing proposition that Archean banded iron formations may have been formed, and diagenetically modified, by anaerobic microbial metabolisms. These efforts encompass a wide array of approaches including isotope, ecophysiological and phylogeny studies, molecular and mineral marker analysis, and sedimentological reconstructions. Herein, the current theories of microbial processes in banded iron formation mineral deposition with particular regard to the mechanisms of chemical sedimentation and post-depositional alteration are described. The main findings of recent years are summarized and compared here, and suggestions are made regarding cross-disciplinary information still required to constrain the role of the biosphere in banded iron formation deposition.
\end{abstract}

Keywords Aerobic and anaerobic Fe(II) oxidation, anoxygenic phototrophs, atmospheric evolution, banded iron formations, cell-mineral aggregates, mineral diagenesis.

\section{INTRODUCTION}

Precambrian banded iron formation (BIF) deposition continues to be a topic of research interest because their mineral and chemical compositions provide direct evidence of the environmental conditions that existed at the time of their deposition. In particular, a number of recent studies have focused on how BIFs can be used as proxies for the emergence of oxygen, from its initial production in the oceans by at least $2.7 \mathrm{Ga}$ (Eigenbrode \& Freeman, 2006; Godfrey \& Falkowski, 2009; Kendall et al.,
2010), to its spread throughout the atmosphere between $2.45 \mathrm{Ga}$ and $2.32 \mathrm{Ga}$, the so-called Great Oxidation Event (GOE) (Rye \& Holland, 1998; Pavlov \& Kasting, 2002; Bekker et al., 2004; Buick, 2008; Farquhar et al., 2011; Konhauser et al., 2011a,b). In this regard, BIFs offer an archive of both early microbial life and the transition to an oxygen-dominated Earth system.

At the heart of understanding the formation of these deposits lies the potential interaction of abiotic and biological processes in these ancient systems; both abiotic and biotic models of formation exist and continue to be explored. The

\footnotetext{
${ }^{1}$ Nordic Centre for Earth Evolution (NordCEE), Institute for Biology, University of Southern Denmark, 5230, Odense, Denmark
} 
relevant question to the efficacy of the microbial models in terms of BIF precipitation is whether the dominant processes of $\mathrm{Fe}(\mathrm{II})$ oxidation and mineral precipitation can be deduced from their: (i) microfossils and fabrics; (ii) stable isotope composition; (iii) biosignature identity; (iv) geochemical composition; and (v) sedimentological features. Moreover, if a biological mechanism was important in the initial process of Fe(II) oxidation in the ancient ocean water column, it is expected that biomass would have settled to the sea floor along with the Fe(III) minerals. This organic carbon would subsequently have served as an oxidizable substrate for sedimentary microbial communities during diagenesis and metamorphism. These post-depositional processes would have modified the initial BIF precursor sediment into the mineral assemblages observed today. Herein, the existing evidence for microbiological involvement in both BIF precipitation and burial is summarized.

\section{BANDED IRON FORMATION SETTING AND DEPOSITIONAL THEORIES}

Banded iron formations are iron-rich ( $\mathrm{ca} 20$ to $40 \% \mathrm{Fe}$ ) and siliceous ( $\mathrm{ca} 40$ to $50 \% \mathrm{SiO}_{2}$ ) sedimentary deposits that precipitated throughout much of the late Archean (2.7 to $2.5 \mathrm{Ga})$ and Palaeoproterozoic ( 2.5 to $1.8 \mathrm{Ga}$ ). The 'Superior' type BIFs, including those in the Hamersley Group, Western Australia, and the Transvaal Supergroup, South Africa, are hundreds of metres thick, over $10^{5} \mathrm{~km}^{2}$ in areal extent and contain $>10^{13}$ tons of iron (Beukes, 1984; Trendall, 2002). These formations are characteristically laminated (James, 1954; Fig. 1), with banding observed over a wide range of scales, from coarse macrobands (metres in thickness) to mesobands (centimetrethick units) to millimetre and sub-millimetre layers (Trendall \& Blockley, 1970). Among the latter are the various varve-like repetitive laminae, known as microbands. Although it is not resolved that these microbands are seasonal, much of the work on these structures is based on that premise.

The mineralogy of the least metamorphosed BIFs consists of chert, magnetite, hematite, carbonates (siderite and dolomite-ankerite), greenalite, stilpnomelane and riebeckite (Klein, 2005; Bekker et al., 2010): the presence of both ferric and ferrous minerals gives BIFs an average oxidation state of $\mathrm{Fe}^{2 \cdot 4+}$ (Klein \& Beukes, 1992). It is generally agreed that none of the minerals in BIFs are primary, but that instead, the mine- rals reflect both diagenetic and metamorphic overprinting. For instance, the primary iron minerals were most probably ferric hydroxide $\left[\mathrm{Fe}(\mathrm{OH})_{3}\right]$, greenalite $\left[(\mathrm{Fe})_{3} \mathrm{Si}_{2} \mathrm{O}_{5}(\mathrm{OH})_{4}\right]$ and siderite $\left(\mathrm{FeCO}_{3}\right)$ (Han, 1966, 1978; Dimroth \& Chauvel, 1973; Perry et al., 1973; Klein, 2005). It has also been suggested that the Archean ocean had significantly elevated concentrations of dissolved silica, at least as high as at saturation with cristobalite $\left(0.67 \mathrm{~mm}\right.$ at $40^{\circ} \mathrm{C}$ in sea water), and possibly even amorphous silica $(2.20 \mathrm{~mm})$ (Maliva et al., 2005; Konhauser et al., 2007a). Under such silica-rich conditions, the precipitation of amorphous silica could have taken place directly on the sea floor (Krapež et al., 2003).

Although BIFs are generally believed to have been deposited on the continental shelf at water depths $>200 \mathrm{~m}$ due to the lack of obvious current and wave-generated structures (Beukes, 1973; Klein \& Beukes, 1992; Morris \& Horwitz, 1983; for review see Klein, 2005), it has been argued that some were deposited off the continental slope in the deep ocean (Krapež et al., 2003). The dominant source of $\mathrm{Fe}(\mathrm{II})$ into the Archean ocean was hydrothermal (Jacobsen \& Pimentel-Klose, 1988; Bau \& Möller, 1993; Hamade et al., 2003), but the proximity of the Fe(II) source to the site of deposition is still unclear. It is believed that the concentration of $\mathrm{Fe}(\mathrm{II})$ in these basins ranged from 0.05 to $0.5 \mathrm{~mm}$ (Holland, 1973; Morris, 1993). On the one hand, Fe could have been delivered from the deep ocean to the outer continental shelf by upwelling currents from a mid-ocean ridge system (Holland, 1973; Morris \& Horwitz, 1983). Accordingly, BIFs would sediment from below the wave base (without the influence of wave and storm-induced currents) onto partially submerged platforms of the continental shelves. On the other hand, the direct supply of $\mathrm{Fe}$ (II) into the photic zone by hydrothermal plumes associated with shallow seamount-type systems (Isley, 1995; Isley \& Abbot, 1999) would curtail the difficulties introduced by the high upwelling rates needed to bring sufficient iron from the deep sea onto the continental shelf (Konhauser, 2007b).

The mineralogy of BIFs dictates that some oxidation of $\mathrm{Fe}(\mathrm{II})$ was necessary for formation, although the dominant mechanism(s) is uncertain (Fig. 2). Prior to the rise of atmospheric oxygen and the development of a protective ozone layer, the Earth's surface was subjected to high levels of ultraviolet (UV) radiation. Bulk ocean waters that were anoxic at this time could have supported high concentrations of dissolved Fe(II). Under 


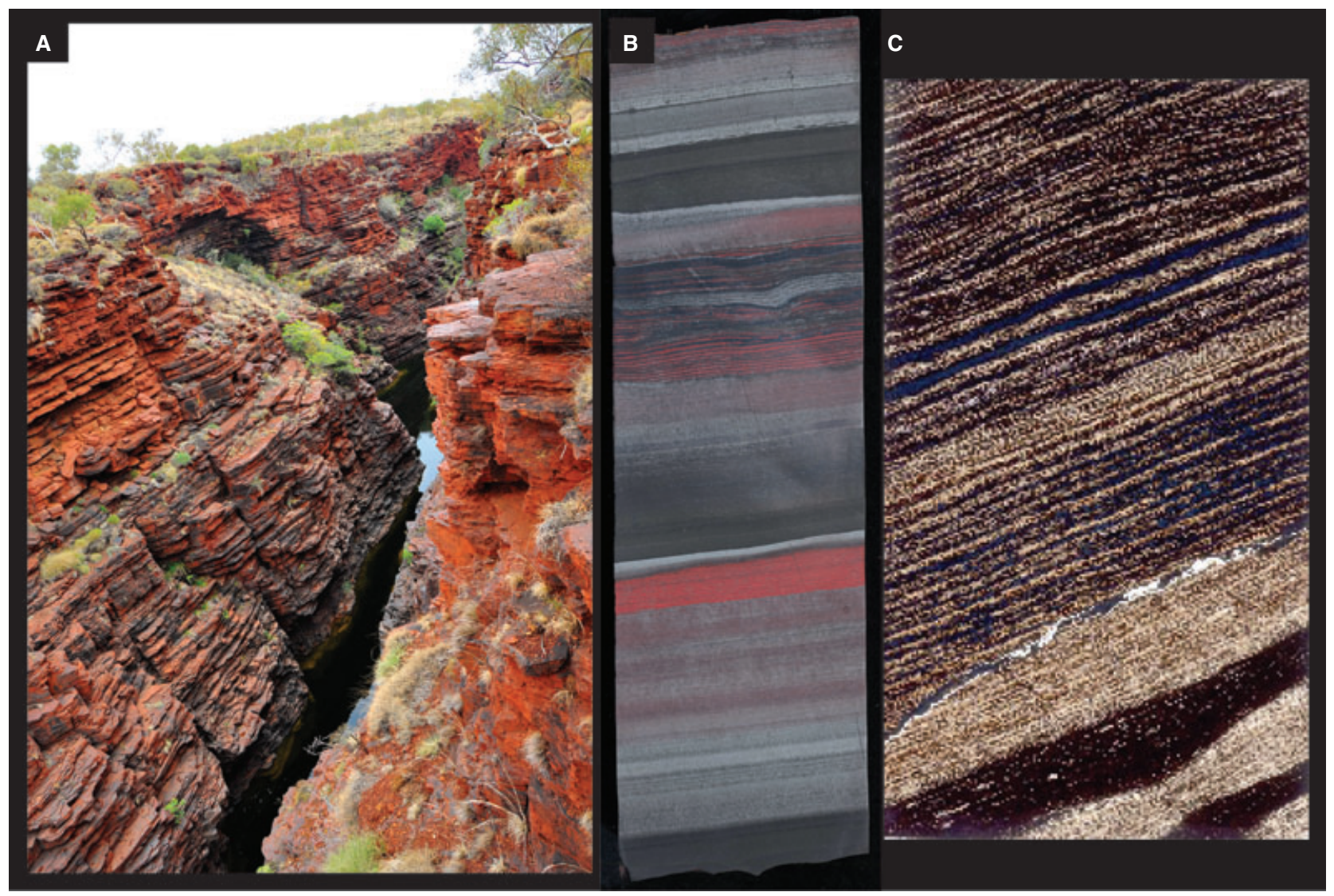

Fig. 1. Overview of the laminated BIF from the Joffre iron formation, Pilbara Craton, north-west Australia. Image courtesy of Stefan Lalonde (A). Core consists of red microbands $(<1 \mathrm{~mm})$ of chert-hematite-riebeckite (bluish bands in upper core) alternating with lighter chert-dolomite-siderite-crocidolite mesobands ( $\geq 1 \mathrm{~cm})$ and denser, dark magnetite mesobands. A slumped chert band due to post-depositional compaction is visible in core top (B). A scanned thin section of the Joffre iron formation in plane-polarized light (C) shows dense blue riebeckite microbands interbedded with brownish hematite/goethite microbands and chert microbands and mesobands. The chert mesobands contain wavy, fine-grained carbonate and hematite/goethite microbands (image scale: $2 \cdot 6 \times 4 \cdot 6 \mathrm{~cm}$ ). Images (B) and (C) courtesy of Rasmus Haugaard.

such conditions, dissolved ferrous iron species, such as $\mathrm{Fe}^{2+}$ or $\mathrm{Fe}(\mathrm{OH})^{+}$, would have absorbed radiation in the 200 to $400 \mathrm{~nm}$ range, leading to the formation of dissolved ferric iron [reaction 1], which, in turn, hydrolysed to form ferric hydroxide at circumneutral pH (Cairns-Smith, 1978; Braterman et al., 1983; Fig. 2A).

$$
2 \mathrm{Fe}_{(\mathrm{aq})}^{2+}+2 \mathrm{H}^{+}+\mathrm{hv} \rightarrow 2 \mathrm{Fe}_{(\mathrm{aq})}^{3+}+\mathrm{H}_{2} \uparrow
$$

However, these experiments focused on determining the specific rates of $\mathrm{Fe}(\mathrm{II})$ photochemical oxidation, and did not simulate the complex, disequilibrium water chemistry characteristic of an ocean where $\mathrm{Fe}(\mathrm{II})$-rich hydrothermal waters reacted with ambient Si-saturated sea water that also contained high concentrations of $\mathrm{HCO}_{3}{ }^{-}$. Indeed, in fluids with high dissolved $\mathrm{Fe}(\mathrm{II})$, $\mathrm{Si}(\mathrm{OH})_{4}$ and $\mathrm{HCO}_{3}{ }^{-}$, the oxidation effects of either UVA or UVC were found to be negligible compared with the precipitation of ferrous-iron silicates (Konhauser et al., 2007b).

As an alternative to the abiological model, the presence of ferric iron minerals in BIFs has also been ascribed to the metabolic activity of planktonic bacteria in the ocean's photic zone. Chemical oxidation of $\mathrm{Fe}(\mathrm{II})$ by photosynthetically produced $\mathrm{O}_{2}$ is one possibility, allowing for the indirect biogenic precipitation of ferric hydroxide (Fig. 2B and C). Under an anoxic atmosphere, this $\mathrm{O}_{2}$ could have been confined to localized 'oxygen oases' associated with cyanobacterial blooms in coastal settings (Cloud, 1965, 1973). Cloud $(1965,1973)$ further proposed that such primitive $\mathrm{O}_{2}$-producing photosynthetic bacteria, which lacked suitably advanced oxygen-mediating enzymes, required ferrous iron to detoxify oxygen. If so, these micro-organisms would have 

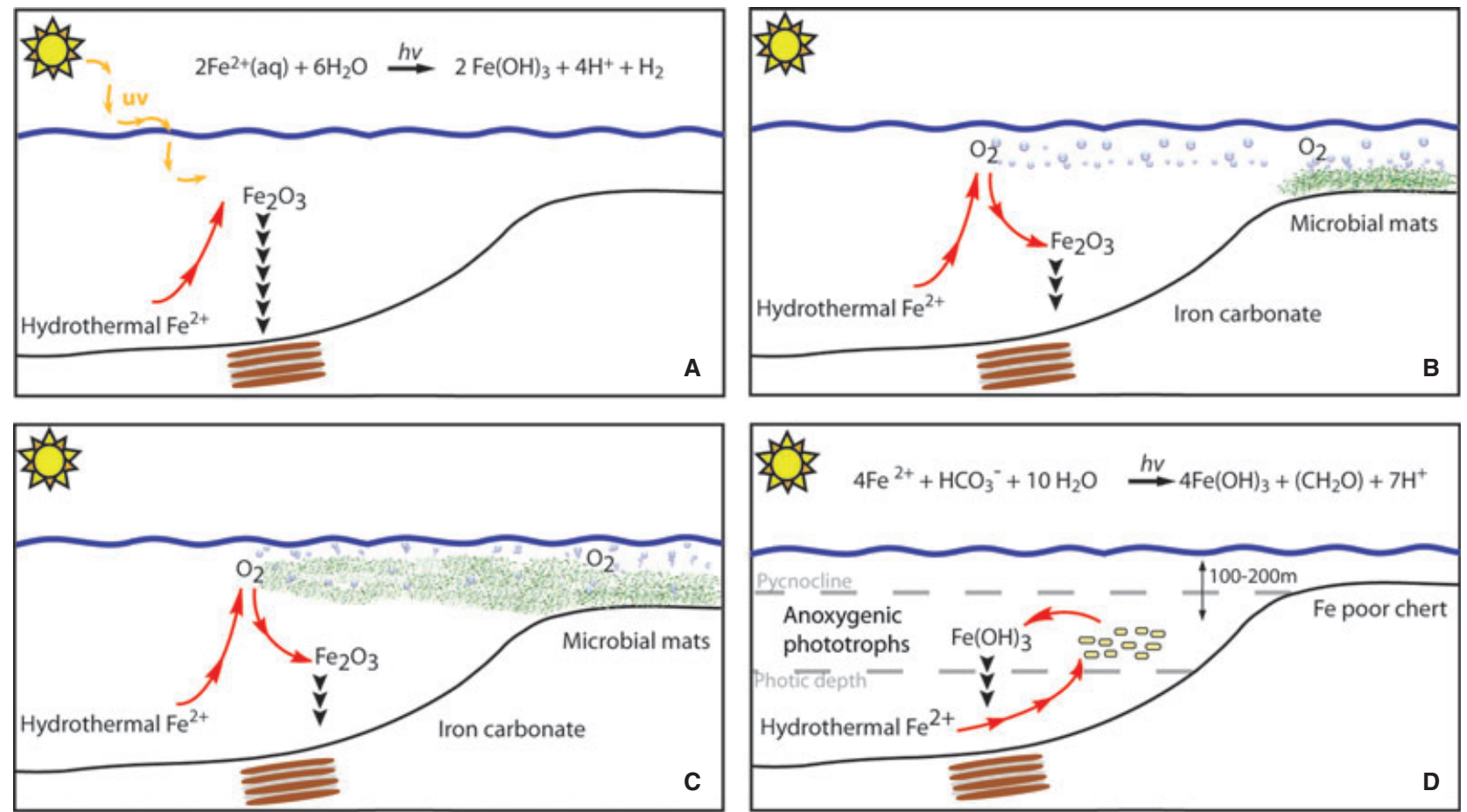

Fig. 2. Models of BIF deposition: For an anoxic water column, the proposed abiotic mechanism of Fe(II) photooxidation by UV light (A). The traditional model of BIF deposition involves production of oxygen by cyanobacteria, which then chemically reacts with hydrothermal dissolved Fe(II). The restriction of cyanobacterial mats to the near-shore would physically separate Fe(III) oxyhydroxides from organic carbon precipitates (B), which would not be the case in a system where cyanobacteria also populated off-shore regions (C). A biotic mechanism of deposition proposed for an anoxic setting is the direct microbial oxidation of Fe(II) via anoxygenic Fe(II)-oxidizing phototrophy (D).

flourished specifically when Fe(II) and nutrients were made episodically available (Cloud, 1969; Fralick \& Pufahl, 2006). Once oxygen was present, microaerophilic Fe(II) oxidizers could have contributed to the direct precipitation of ferric hydroxide (Holm, 1989).

Garrels et al. (1973) and Hartman (1984) later suggested that light, not $\mathrm{O}_{2}$, may have coupled the carbon and iron cycles, via photosynthesis that used $\mathrm{Fe}$ (II) rather than $\mathrm{H}_{2} \mathrm{O}$ as an electron donor, producing $\mathrm{Fe}$ (III) rather than $\mathrm{O}_{2}$ (Fig. 2D). With the evolution of this photoferrotrophy, biological Fe(II) oxidation would have superseded photochemical oxidation because the bacteria could grow deeper in the water column where UV radiation would be effectively absorbed (Konhauser et al., 2002). Modelling of experimentally determined photosynthetic Fe(II) oxidation rates even suggests that such micro-organisms could have accounted for all of the Fe(III) initially deposited in primary BIF sediment (Kappler et al., 2005).

Although the average oxidation state of the iron in BIFs $\left(\mathrm{Fe}^{2 \cdot 4+}\right)$ can be attributed to the simultaneous deposition of $\mathrm{Fe}(\mathrm{II})$ and $\mathrm{Fe}(\mathrm{III})$, the partial microbial or abiotic reduction of $\mathrm{Fe}(\mathrm{III})$ to
Fe(II) can also explain this mixed oxidation state. The presence of magnetite as: (i) disseminated grains within but obscuring sedimentary laminae; (ii) laminated beds that clearly truncate sedimentary layering; and (iii) cleavage fills, suggests a secondary origin to magnetite in BIFs (Ewers \& Morris, 1981; Krapež et al., 2003). Microbial $\mathrm{Fe}(\mathrm{III})$ reduction is carried out by anaerobic heterotrophic bacteria that link this process to organic matter oxidation (Lovley \& Phillips, 1988). Fe(III) oxyhydroxides can also be abiotically reduced after sedimentation with a reductant, such as the organic carbon associated with planktonic bacteria necromass, and can produce siderite $\left(\mathrm{FeCO}_{3}\right)$ and magnetite $\left(\mathrm{Fe}_{3} \mathrm{O}_{4}\right)$ (Schaedler et al., 2009; Posth et al., 2010). Recent experiments point to the production of siderite spherulites, also found in many BIFs, by the experimental diagenesis of ferrihydrite and glucose at relevant pressure and temperature. Three lines of evidence point to the antiquity of such an anaerobic respiratory pathway. Firstly, extant hyperthermophilic Bacteria and Archaea branch deeply in the universal phylogenetic tree and can reduce Fe(III) (Vargas et al., 1998). Secondly, highly negative $\delta^{56} \mathrm{Fe}$ values in magnetite-rich 
BIF samples as old as 2.9 Ga have been observed (Johnson et al., 2003; Yamaguchi et al., 2005) and are comparable to the negative fractionations measured in experimental culture with dissimilatory $\mathrm{Fe}(\mathrm{III})-$ reducing bacteria (Johnson et al., 2005). Thirdly, Li et al. (2011) recently conducted high-resolution mineral analyses of the 2.48 Ga Dales Gorge BIF in Western Australia and reported the detection of an $\mathrm{Fe}(\mathrm{III})$-acetate salt, as well as nanocrystals of apatite in association with magnetite; the latter had a crystal chemistry identical to modern biogenic magnetite. This combination of features points to the original presence of biomass in the BIF sediments, and also indicates that the organic carbon served as an electron donor during bacterial Fe(III) reduction.

Crucial to understanding of the biological role in BIF formation is an assessment of the relation between biomass production and the BIF depositional setting. To this end, results of physiological experiments give a sense of the viable range of initial phototrophic productivity in the ocean's photic zone and of precipitated cell-Fe $(\mathrm{OH})_{3}$ aggregate composition. Investigation of the redox properties and the cycling of elements have also proven valuable in the reconstruction of the microbial role at the time of BIF deposition. The utilization of $\mathrm{H}_{2} \mathrm{O}$ by cyanobacteria and the direct oxidation of $\mathrm{Fe}(\mathrm{II})$ by photoferrotrophs are both coupled to $\mathrm{CO}_{2}$ reduction and biomass production. Ferric hydroxide particles and organic biomass could be deposited in either case. In the photoferrotroph model, direct Fe(II) oxidation by the cells would lead to a joint sedimentation of precipitated Fe(III) and microbially produced biomass. In the cyanobacteria model, the production of $\mathrm{O}_{2}$ by the cells, and the oxidation of the $\mathrm{Fe}(\mathrm{II})$ by this $\mathrm{O}_{2}$ are independent. Consequently, the potential association of the $\mathrm{Fe}(\mathrm{III})$ minerals with the cyanobacterial biomass depends on the local distribution of the cells relative to the location of $\mathrm{Fe}$ (III) mineral deposition (open ocean or shore, Fig. 2C).

\section{EVIDENCE FOR ANCIENT CYANOBACTERIA}

\section{Microfossils and biological fabrics}

The timing of the origins of cyanobacteria remains highly controversial. For many years, the oldest morphological evidence for cyanobacteria was believed to have come from weathered clasts in the $3.45 \mathrm{Ga}$ Apex cherts of the
Warrawoona Group, Western Australia. Structures reminiscent of unbranched, partitioned trichomes, with dimensions and morphologies indicative of extant cyanobacteria, led to the suggestion that the Archean micro-organisms were capable of gliding and, possibly, phototactic motility (Schopf, 1993). Moreover, confocal laser scanning microscopy of the filaments and Raman spectroscopy were used to infer the presence of biogenic kerogen in higher concentrations than the surrounding matrix (Schopf et al., 2002; Schopf \& Kudryavtsev, 2009). Additional support for the early evolution of cyanobacteria came from the discovery of large spheroidal, sheath-like structures (up to $20 \mu \mathrm{m}$ in diameter) in cherts from the underlying Towers Formation (Schopf \& Packer, 1987), as well as from the presence of conical and pseudocolumnar stromatolites in the 3.4 Ga Strelley Pool Chert, Western Australia (Van Kranendonk, 2006).

A re-examination of the Apex chert by Brasier et al. (2002, 2005), however, called into question the biogenicity of the filamentous structures and the sedimentary origins of the earliest 'fossiliferous' deposits, citing Fischer-Tropsch-type reactions associated with sea floor hydrothermal systems. Buick (1988) has maintained that the actual chert units from which these microfossils derive are secondary hydrothermal deposits of much younger age that cross-cut the primary bedding. The Warrawoona samples also led to experiments which demonstrate that kerogen in a microfossiliferous sample does not in itself indicate biogenicity. Simple organic hydrocarbons, whose sources are abiological (formaldehyde), readily condense onto silica-carbonate inorganic filaments and subsequently polymerize under gentle heating to yield kerogenous products (Garcia-Ruiz et al., 2003). Indeed, the same kind of Raman spectral signature is obtained from kerogen as stems from many other poorly ordered and abiogenic carbonaceous materials (Pasteris \& Wopenka, 2003). Furthermore, a recent study focusing on similar structures from the Apex chert using Raman spectroscopy showed that the microstructures were a mixture of hematite and quartz and that the matrix did in fact consist of carbonaceous material, but the interpretation of the original structures as biogenic was a result of image compilation (Marshall et al., 2011). Thus, the discussion surrounding the Warrawoona samples demonstrates that the presence of carbonaceous material is not sufficient proof of biogenicity. Importantly, it highlights the stringent criteria 
needed to determine bona fide biogenicity in ancient rocks (for further discussion on these criteria, see Schopf et al., 2007). A firmer benchmark for the presence of cyanobacteria comes from the $2 \cdot 7 \mathrm{Ga}$ stromatolitic assemblages of the Tumbiana Formation, Western Australia. Based on their habitat in a sulphate-deficient evaporative lake, it was suggested that the original microbial mat contained cells that were metabolized by oxygenic photosynthesis (Buick, 1992). This view is supported by the earliest recognized fossil assemblage of filamentous and coccoid cells colonies, from the $2 \cdot 6 \mathrm{Ga}$ Campbell Group, South Africa, which appears to include oscillatoriacean cyanobacterial genera, such as Phormidium or Lyngbya. These micro-organisms contributed to the formation of stromatolitic reefs in shallow subtidal to intertidal settings (Altermann \& Schopf, 1995). Other possible examples of ancient cyanobacteria occur in laminates and oolites of the $2.5 \mathrm{Ga}$ Gamohaan Formation, South Africa, where Wright \& Altermann (2000) reported dolomicrites formed on the outer margins of the sheaths of filamentous cyanobacterial remains. More putative evidence for cyanobacteria stems from the 2.9 Ga Pongola Supergroup in South Africa, where Noffke et al. (2008) observed microbially influenced sedimentary structures that are consistent with similar features constructed today by benthic cyanobacteria.

The link between oxygenic photosynthesis and stromatolite formation is supported by modern studies which show that the trapping and binding of carbonate grains by cyanobacterial filaments and their extracellular polymers (such as extracellular polymeric substances) are integral to the structure of intertidal stromatolites (Burns et al., 2004, 2009; Bosak et al., 2009). However, a series of studies show how similar structures can be formed via abiological processes (Grotzinger \& Rothman, 1996; Grotzinger \& Knoll, 1999; McLoughlin et al., 2008). In addition, sequence analysis of small sub-unit rRNA genes amplified with PCR from genomic DNA of modern stromatolite communities of Hamelin Pool, Shark Bay, Australia, showed that anoxygenic phototrophs represent a considerable fraction of the biomass (Papineau et al., 2005). Along the same lines, Bosak et al. (2007) later demonstrated that the anoxygenic phototroph, Rhodopseudomonas palustris, stimulates the precipitation of calcite in saturated solutions and builds stromatolitelike structures. It has been suggested that before cyanobacteria evolved, ferrous iron was the main reductant in ancient oceans; only with depletion in ferrous iron supply to the oceans did $\mathrm{H}_{2} \mathrm{O}_{2}$ and then water replace ferrous iron as the electron donor in the cyanobacterial line of evolution (Olson \& Blankenship, 2004). It seems possible that prior to the rise of cyanobacteria, predecessor anaerobes, such as anoxygenic phototrophs, were dominant stromatolite-building organisms, which could account for the stromatolitic record that pre-dates strong evidence for oxygenic phototrophs. Further studies into the mechanisms of stromatolite formation promise to help parse the dominant processes to use these structures more accurately in ecosystem reconstruction.

\section{Stable isotope composition}

One persuasive argument in favour of early $\mathrm{CO}_{2}$ fixation via photosynthesis, and the potential presence of cyanobacteria, comes from the highly negative carbon isotopic values of kerogen residues in Archean strata. The negative values are seemingly indicative of life because the transformation of inorganic carbon (for example, $\mathrm{CO}_{2}$ or $\mathrm{HCO}_{3}{ }^{-}$) via autotrophic pathways into organic carbon involves the preferential incorporation of the lighter isotope, ${ }^{12} \mathrm{C}$, into the organic material, leaving behind a reservoir enriched in the heavier isotope, ${ }^{13} \mathrm{C}$. Consequently, organic compounds produced by autotrophic pathways display a marked preference for the light isotope (for example, $\delta^{13} \mathrm{C}$ in cyanobacteria range from -4 to $-35 \%$ o), whereas the heavy carbon is retained in the surface reservoir of oxidized carbon, mostly as dissolved bicarbonate, and later incorporated into precipitated carbonate minerals, for example, calcite and dolomite, or as atmospheric $\mathrm{CO}_{2}$ (Schidlowski, 2000).

Analysis of kerogens in microfossiliferous units in Archean formations from Western Australia and South Africa contain negative carbon isotopic values that range from -20 to $-35 \%$ (Altermann \& Kazmierczak, 2003; Tice \& Lowe, 2004), whereas the organic carbon in early Proterozoic cherts similarly averages $c a-31 \cdot 0 \pm 4 \cdot 7$ (Strauss et al., 1992). More recently, a study of the C-isotope signatures in the Transvaal Supergroup showed the organic $\delta^{13} \mathrm{C}$ to range from -40 to $-25 \%$ (Fischer et al., 2009). Collectively, these results are an indication of early photosynthesis. Unfortunately, a number of carbon fixation pathways (Calvin cycle and the reductive acetyl-CoA, reductive citric acid and hydroxypropionate pathways) utilized by phototrophic 
bacteria seem to have overlapping degrees of carbon isotope fractionation, which hinders conclusive interpretation.

Strong evidence for oxygen in the Archean oceans comes from extremely isotopically depleted kerogens from 2.72 to $2.59 \mathrm{Ga}$ carbonates and shales in the Hamersley Province in Western Australia. Organic carbon ${ }^{13} \mathrm{C}$ values range from as low as -57 to $-28 \%$ o (Eigenbrode \& Freeman, 2006). The ${ }^{13} \mathrm{C}$ enrichment has been ascribed to the assimilation of methane by methanotrophic bacteria that utilize electron acceptors such as $\mathrm{O}_{2}, \mathrm{SO}_{4}{ }^{2-}$ or $\mathrm{NO}_{3}{ }^{-}$; both sulphate and nitrate require oxygen for their formation (Hayes, 1983). Potentially, although not yet conclusively demonstrated, methane oxidation could be linked to the reduction of $\mathrm{Fe}(\mathrm{III})$ (Konhauser et al., 2005). Interestingly, there is a ${ }^{13} \mathrm{C}$ enrichment of $10 \%$ in kerogen in post2.7 Ga shallow-water facies relative to the deepwater facies, suggesting that the shallow setting became oxygenated, marginalizing the methanogens and methanotrophs to deeper waters, whereas the shallow waters became dominated by cyanobacteria (Eigenbrode \& Freeman, 2006).

\section{Biomarker identity}

An additional tool for the identification of a specific group of organisms in ancient rocks is the analysis of organic biomarkers. These organic compounds, derived from more complex precursors, retain some resemblance to the original biological molecules, even after a long history of decomposition and alteration that accompanies burial and diagenesis. Bitumens from the $2 \cdot 6 \mathrm{Ga}$ Marra Mamba Iron Formation and the $2.5 \mathrm{Ga}$ Mount McRae Shale of the Hamersley Group, Western Australia, for example yield abundant $2 \alpha$-methylhopanes, derivatives of prominent lipids in cyanobacteria (methyl-bacteriohopanepolyols) that serve to improve cell membrane rigidity (Brocks et al., 1999; Summons et al., 1999; Eigenbrode et al., 2008).

These compounds were first strictly found in cyanobacteria and, therefore, were interpreted as diagnostic of oxygenic photosynthetic organisms in ancient rocks. The belief that they only served a structural function, however, made it difficult to connect the presence of these compounds to a specific metabolism. Genomic databases revealed that several facultative and obligate anaerobes possess the appropriate genes for hopanoid biosynthesis. In fact, Geobacter sulfurreducens actually produces a wide variety of complex hopanoids structurally related to $2 \alpha$ methylhopane under strictly anoxic conditions in pure culture (Fischer et al., 2005; Härtner et al., 2005). It has been demonstrated that an anoxygenic Fe(II)-oxidizing phototroph, $R$. palustris strain TIE-1, generates substantial quantities of 2-methylhopanoids in the absence of oxygen (Rashby et al., 2007). Utilizing this same strain, a recent study now shows that C-2 methylated hopanoids are preferentially synthesized by the $R$. palustris strain TIE-1 under conditions of elevated $\mathrm{Fe}(\mathrm{II})$ concentrations (Eickhoff et al., 2013). Accordingly, their presence in the rock record may also signal anoxic ferrous conditions. Although the full physiological roles of 2-methylhopanoids are still not defined, it seems that their origins are more diverse than first believed.

Hopanes carrying 3-methyl substituents have also been recovered from 2.72 to 2.56 Ga carbonates and shales from the Hamersley Province (Eigenbrode et al., 2008). The only known extant bacteria to produce these particular hopanes are aerobic methanotrophs. Their presence, and strong correlation with the carbon isotope compositions in kerogen (as discussed in the previous section), may thus confirm the presence of oxygen in the photic zone by the late Archean.

A third suite of biomarkers, specific steranes of 28 to 30 carbon isomers, are unique alteration products of the sterols used in extant eukaryotic cell membranes. The only prokaryotes known to synthesize sterols have biosynthetic pathways leading to different structural isomers. Because $\mathrm{O}_{2}$ is required for the biosynthesis of sterols, their extraction from Archean rocks suggests that at least some dissolved oxygen ( $\mathrm{ca} 0.002 \mathrm{ml} \mathrm{O}_{2} \mathrm{l}^{-1}$ ) was present at that time. These steranes were reported in bitumens of the $2.7 \mathrm{Ga}$ shales of the Jeerinah Formation, Hamersley Group (Brocks et al., 1999). This finding was later questioned as a subsequent study suggested that the samples were contaminated by younger fluids (Rasmussen et al., 2008). In recent experiments using the yeast Saccharomyces cerevisiae as a test organism, steroid biosynthesis was observed at dissolved $\mathrm{O}_{2}$ concentrations ranging from $6.5 \mu \mathrm{M}$ to $7 \mathrm{~nm}$ (Waldbauer et al., 2011), suggesting that very low $\mathrm{O}_{2}$ concentrations were sufficient for steroid biosynthesis. There is still no experimental evidence to support the alternative theory that steranes may have been produced via an anaerobic pathway utilizing hydrogen peroxide or organic peroxides (Raymond \& Blankenship, 2004; Fischer \& Pearson, 2007). 


\section{Geochemical composition}

At present, there is a temporal gap in the rock record with regard to the geochemical evidence for the evolution of cyanobacteria and the effects of their metabolism on atmospheric oxygenation. In addition to the features described above that support cyanobacterial evolution $c a 2.7 \mathrm{Ga}$, there are geochemical signatures in various lithologies that point towards the presence of shallow oxygenated sea water by the Neoarchean. Firstly, nitrogen isotopic composition of kerogens in minimally altered shales from the Campbellrand-Malmani platform in South Africa showed a significant rise in the $\delta^{15} N$ values by $2.67 \mathrm{Ga}$ (Godfrey \& Falkowski, 2009). This increase has been proposed as evidence for the onset of nitrification-denitrification reactions in the surface oceans; importantly, these microbial processes require the presence of oxygen. Secondly, a recent study of the trace element composition of those same shales showed a high abundance of Re but a low abundance of Mo, which together with the speciation of sedimentary iron, confirms the presence of oxygen in the water column, arguably to depths of several hundred metres (Kendall et al., 2010). In contrast to the above, a number of features suggest that the atmosphere did not contain significant amounts of oxygen until $c a 200$ Myr later at $c a$ $2.5 \mathrm{Ga}$, the so-called Great Oxidation Event. These include:

1 Detrital uraninite, pyrite and siderite that are easily oxidized by $\mathrm{O}_{2}$ have been recovered in fluvial siliciclastic sediments of the $3 \cdot 2$ to $2 \cdot 7$ Gyr Pilbara craton (Rasmussen \& Buick, 1999). They are not abundant in fluvial systems younger than $2 \cdot 3 \mathrm{Ga}$.

2 High-resolution chemostratigraphy reveals an episode of enrichment of the redox-sensitive transition metals molybdenum and rhenium in the 2.5 Ga Mount McRae Shale in Western Australia (Anbar et al., 2007). These findings suggest that the metals were supplied to the oceans by oxidative weathering of crustal sulphide minerals. Similarly, a recent compilation of $\mathrm{Cr}$ concentrations in BIFs shows an enrichment beginning at $2.45 \mathrm{Ga}$ (Frei et al., 2009; Konhauser et al., 2011b). Given the insolubility of Cr minerals, its mobilization and incorporation into BIFs indicates enhanced chemical weathering at that time, likely associated with the evolution of aerobic continental pyrite oxidation.

3 Iron speciation and sulphur isotope data from the Mount McRae Shale provide evidence for euxinic (anoxic and sulphidic) layers in the water column by $2.5 \mathrm{Ga}$ (Reinhard et al., 2009). These conditions were probably stimulated by an increase in oceanic sulphate concentrations arising from aerobic continental pyrite oxidation. Correspondingly, previous low levels of marine sulphate suggest minimal oxidative weathering of sulphide minerals (Canfield et al., 2000).

4 Mass-independent fractionation (MIF) of sulphur isotopes $\left(\Delta^{33} S\right.$ and $\left.\Delta^{36} S\right)$ in sulphide and sulphate-containing rocks deposited prior to $2.45 \mathrm{Ga}$, but not after $2.32 \mathrm{Ga}$. This observation indicates that the sulphur cycle changed from one governed by gas-phase photochemical reactions in an $\mathrm{O}_{2}$-deficient atmosphere to one dominated by oxidative weathering, where the different sulphur species lost their MIF signal due to microbial $\mathrm{SO}_{4}{ }^{2-}$ reduction (Farquhar et al., 2000; Mojzsis et al., 2003; Bekker et al., 2004). To preserve the MIF in Archean and early Palaeoproterozoic sediments, the atmospheric oxygen concentration must have been $<10^{-5}$ present atmospheric levels (PAL). By contrast, in atmospheres with $\mathrm{O}_{2}$ concentrations $>10^{-5}$ PAL, reduced sulphur-bearing species would typically have been oxidized to sulphate before becoming incorporated into the sediment, so any MIF signature would have been lost (Pavlov \& Kasting, 2002). A more recent and comparative study utilizing investigations of the Mount McRae Shale and correlating it to the Gamohaan and Kuruman iron formations of South Africa dates the progressive rise of oxygen at $2.5 \mathrm{Ga}$ and implies that this phenomenon was certainly on a widespread, if not global, scale (Kaufman et al., 2007).

\section{EVIDENCE FOR PHOTOFERROTROPHS}

Given that pre-2.7 Ga BIFs probably were precipitated from anoxic sea water, and the various uncertainties regarding the presence of cyanobacteria in the rock record, it is relevant to consider BIF precipitation mechanisms based on the direct biological oxidation of $\mathrm{Fe}(\mathrm{II})$ via anoxygenic photosynthesis (Cloud, 1965, 1973; Garrels et al., 1973; Hartman, 1984). Although there is still no actual physical or chemical evidence for the existence of Fe(II)-oxidizing phototrophs in the Archean, six independent lines do suggest their presence on the early Earth. 


\section{Phylogenetic analysis}

Of the seven known strains of anoxygenic Fe(II)oxidizing phototrophs known to date, six of them have been classified as Proteobacteria; the seventh is a green sulphur bacterium (Table 1). The Proteobacteria are a large and diverse phyla of bacteria consisting of five major classes; alpha [including $\mathrm{Fe}(\mathrm{II})$-oxidizing purple non-sulphur bacteria], beta, gamma [including Fe(II)-oxidizing purple sulphur bacteria], delta and epsilon, all of which may have diversified from one ancestral phototroph (Woese, 1987). Purple sulphur and purple non-sulphur bacteria use bacteriochlorophyll (Bchl $a$ or $b$ ) to absorb light in the near-infrared (800 to $1040 \mathrm{~nm}$ ). Although controversy has arisen from phylogenetic studies of anoxygenic and oxygenic photosynthesis due to partial gene loss and fast lateral transfer of Bchl biosynthesis genes, molecular phylogenetic analyses of a number of enzymes involved in Bchl biosynthesis suggests that anoxygenic photosynthetic lineages are almost certain to be more deeply rooted than the oxygenic cyanobacterial lineages (Xiong, 2006).

\section{Ecophysiological studies with extant species of anoxygenic Fe(II)-oxidizing phototrophs}

Although the plausibility of an anoxygenic Fe(II)oxidizing metabolism had long been speculated based on thermodynamic considerations (Garrels et al., 1973; Hartman, 1984), such organisms were discovered more recently and subsequently isolated (Widdel et al., 1993). A number of experimental studies have since confirmed that various purple and green phototrophic bacteria, both fresh water and marine (Table 1), can use $\mathrm{Fe}(\mathrm{II})$ as a reductant for $\mathrm{CO}_{2}$ fixation [reaction 2] (Widdel et al., 1993; Heising et al., 1999; Straub et al., 1999). This fact has made it possible to study these organisms as potential modern analogues of ancient organisms.

$4 \mathrm{Fe}^{2+}+\mathrm{HCO}_{3}^{-}+10 \mathrm{H}_{2} \mathrm{O} \rightarrow 4 \mathrm{Fe}(\mathrm{OH})_{3}+\left(\mathrm{CH}_{2} \mathrm{O}\right)+7 \mathrm{H}^{+}$

Anoxygenic Fe(II) oxidizing phototrophs are diverse and broadly distributed in the environment (Table 1). None of these organisms are unique in form as all are rod-shaped (Fig. 3); however, morphological variety is apparent, for example, the presence of vacuoles in Thiodictyon sp. strain F4 (Croal et al., 2004). Furthermore, these strains are capable of utilizing a variety of substrates, such as acetate, $\mathrm{H}_{2}$ and even $\mathrm{FeS}$, and were shown to oxidize $\mathrm{Fe}(\mathrm{II})$ even in the presence of $\mathrm{H}_{2}$ (Croal et al., 2009). This diversity suggests that these organisms have the potential to be ubiquitous in both ancient and modern anoxic, Fe-rich environments.

Importantly, although the Fe(II) oxidation rate of these strains is dependent on light intensity, anoxygenic phototrophs are capable of oxidizing $\mathrm{Fe}(\mathrm{II})$ in low light regimes befitting the photic zone of ocean water (Kappler et al., 2005; Hegler et al., 2008). Considering the highly efficient light harvesting mechanism employed by anoxygenic phototrophs, it was estimated that, even in the presence of an overlying layer of cyanobacteria, sufficient light for the metabolism of anoxygenic phototrophs could penetrate up to $100 \mathrm{~m}$ ocean depth (Kappler et al., 2005). Similar light harvesting has been seen in the Black Sea, with anoxygenic phototrophs detected at a depth of 80 to $100 \mathrm{~m}$ (Overmann et al., 1992; Manske et al., 2005). These strains also continue to carry out the oxidation of $\mathrm{Fe}(\mathrm{II})$ in the presence of a wide range of $\mathrm{Fe}(\mathrm{II})$ concentrations, with

Table 1. The anoxygenic Fe(II)-oxidizing phototrophs isolated to date include both marine and fresh water strains.

\begin{tabular}{|c|c|c|}
\hline Phylum & Strain & Setting/location \\
\hline $\begin{array}{l}\alpha \text {-Proteobacteria } \\
\text { (purple non-sulphur) }\end{array}$ & $\begin{array}{l}\text { Rhodobacter ferrooxidans sp. strain SW2 } \\
\text { Rhodopseudomonas palustris strain TIE-1 } \\
\text { Rhodomicrobium vannielii strain BS-1 } \\
\text { Rhodovulum iodosum } \\
\text { Rhodovulum robiginosum }\end{array}$ & $\begin{array}{l}\text { Fresh water ponds, Hannover Germany }{ }^{1} \\
\text { Fe-rich mat, Woods Hole, MA, USA }{ }^{6} \\
\text { Fresh water ditch, Tübingen, Germany }{ }^{2} \\
\text { Marine mud flat, North Sea, Germany } \\
\text { Marine mud flat, North Sea, Germany }\end{array}$ \\
\hline $\begin{array}{l}\gamma \text {-Proteobacteria } \\
\text { (purple sulphur) }\end{array}$ & Thiodictyon sp. strain F4 & Fresh water marsh, North Sea, Germany ${ }^{5}$ \\
\hline Green sulphur & Chlorobium ferrooxidans sp. strain KoFox & Fresh water ditch, Constance, Germany ${ }^{3}$ \\
\hline
\end{tabular}

${ }^{1}$ Ehrenreich \& Widdel (1994), ${ }^{2}$ Heising \& Schink (1998), ${ }^{3}$ Heising et al. (1999), ${ }^{4}$ Straub et al. $(1999),{ }^{5}$ Croal et al. (2004), ${ }^{6}$ Jiao et al. (2005).

(C) 2013 The Authors. Journal compilation (C) 2013 International Association of Sedimentologists, Sedimentology, 60, 1733-1754 

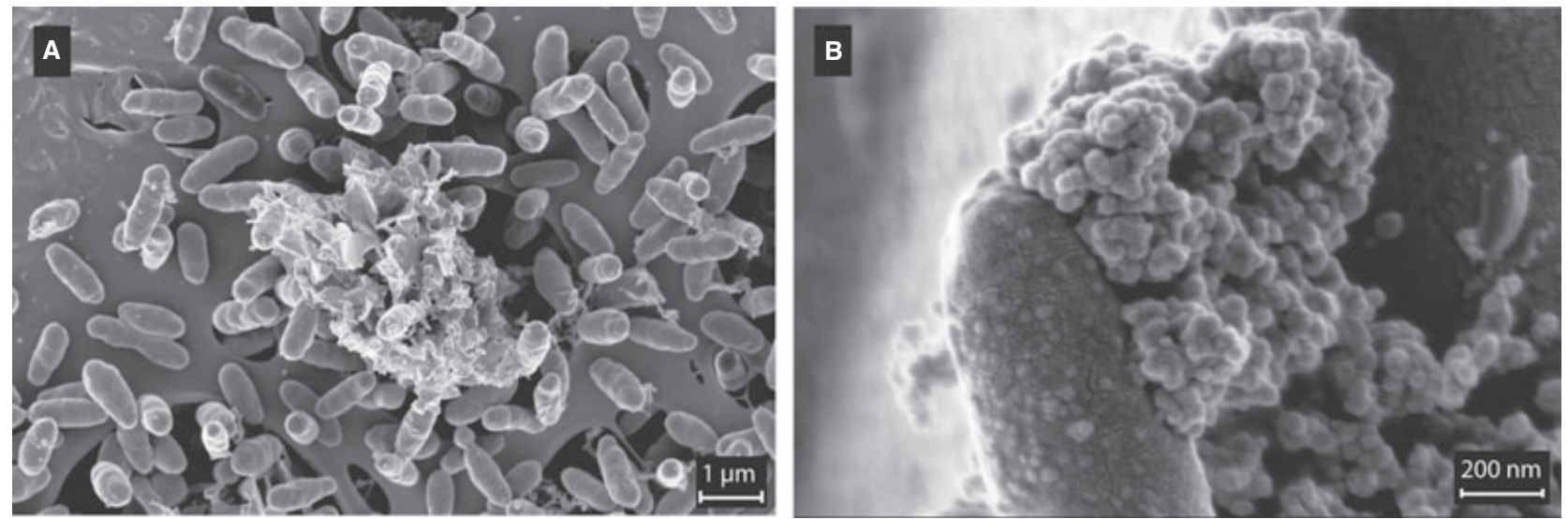

Fig. 3. Anoxygenic Fe(II)-oxidizing phototrophic Rhodobacter ferrooxidans sp. strain SW2 cells form aggregates with the Fe(III) oxyhydroxides produced by their metabolism. Many cells are not encrusted by, but rather are associated with, the Fe(III) minerals (A), or are only partially coated (B).

reported values between $0.5 \mathrm{~mm}$ and $30 \mathrm{~mm}$ (Hegler et al., 2008). This observation suggests that, even in ancient sea water with variations of $\mathrm{Fe}(\mathrm{II})$ concentrations due to a pulsed input of hydrothermal Fe(II), anoxygenic phototrophs could have continued to metabolize.

It has also been shown that Fe(II) oxidation is not hindered by the high concentrations of silica (2 mM) estimated for the Archean oceans (Siever, 1992; Konhauser et al., 2007a). Indeed, the temperature dependence of anoxygenic Fe(II) oxidation in growth medium containing dissolved $\mathrm{Fe}(\mathrm{II})$ and dissolved silica suggests that a coupled abiotic-biotic mechanism may be involved in deposition of the alternating Fe-rich and Si-rich BIF layering (Posth et al., 2008). Although demonstrated in a simplified laboratory system, these experiments show that, at temperatures suitable for Fe(II)-oxidizing phototrophs, the $\mathrm{Fe}(\mathrm{III})$ oxyhydroxides they produce will precipitate, whereas silica largely stays in solution. At cooler temperatures, silica will precipitate out abiotically whereas the bacteria cease measureable Fe(II) oxidation until temperatures once again increase.

\section{Availability of substrates}

Modern anoxygenic phototrophs are able to utilize multiple substrates. In Archean oceans, phototrophic bacteria would not have had access to large quantities of sulphide as an electron donor because any hydrothermally sourced dissolved sulphide would have reacted with $\mathrm{Fe}(\mathrm{II})$ near the vent and thus precipitated as solid-phase sulphide minerals. In the case of limited $\mathrm{HS}^{-}$supply, the ability of bacteria to use
$\mathrm{Fe}(\mathrm{II})$ as a reductant is predictable. In fact, even considering higher hydrogen concentrations (Kump \& Barley, 2007), Fe(II) oxidation by modern analogue anoxygenic phototrophs still proceeds at significant rates under an atmosphere containing approximately three times the maximum predicted concentration of $\mathrm{H}_{2}$ in the Archean atmosphere (Croal et al., 2009). The input of dissolved Fe(II) from mid-ocean ridges was almost certainly greater during the Archean, a view supported by the presence of excess Fe in sandstones and shales of that time (Kump \& Holland, 1992). Thus, it seems likely that these organisms applied enzymatic systems to use abundantly available electron donors, such as $\mathrm{Fe}^{2+}$ [reaction 2]. In addition, it was suggested that $\mathrm{Fe}(\mathrm{II})$ oxidation and $\mathrm{Fe}(\mathrm{III})$ precipitation may even have provided an external UV protecting shield for planktonic cells (Pierson, 1994; Phoenix et al., 2001).

\section{Biomarker identity}

Recent analysis of the 1.64 Ga Barney Creek Formation in northern Australia, a marine, subtidal unit, yielded okenane, the fossil hydrocarbon biomarker of the precursor, okenone. This carotenoid pigment is exclusively found in purple sulphur bacteria and in recent sediments under euxinic conditions (Brocks, 2005). The presence of these biomarkers, therefore, strongly suggests that purple sulphur bacteria [that have representatives that are able to oxidize $\mathrm{Fe}(\mathrm{II})$ phototrophically] were present in high numbers, at least in the Palaeoproterozoic oceans. In addition, the discovery of 2-methlyhopanoids in cultures of the anoxygenic Fe(II)-oxidizing 
phototroph, $R$. palustris strain TIE-1 stimulated by environmental $\mathrm{Fe}(\mathrm{II})$ in the absence of oxygen (Rashby et al., 2007) demonstrates the utility of this biomarker in reconstructing anoxygenic phototrophy in ancient sediment.

\section{Stable isotope composition}

Large variations of $\delta^{56} \mathrm{Fe}(-2 \cdot 5$ to $1 \cdot 0 \%$ relative to the bulk Earth) in late Archean and early Palaeoproterozoic BIFs from the Transvaal Supergroup, South Africa, incorporate the entire range of values measured on Earth and are interpreted to highlight the role of fluid-mineral isotope fractionation and, possibly, microbial processes (Johnson et al., 2003). Although $\mathrm{Fe}$ isotope variations have the potential to define ancient sedimentary environments and could help distinguish between biotic and abiotic processes, as well as whether post-depositional processes may have altered the Fe redox state in BIFs, the complexity of the depositional environments and infiltration of external fluids during diagenesis and/or low temperature metamorphism may erase the primary isotope record (Hoefs, 1997; Johnson et al., 2003). Yet, the Fe isotope composition of iron minerals in BIFs are markedly different from the homogenous values seen in igneous rocks and many modern marine sediments $\left(\delta^{56} \mathrm{Fe} 0 \cdot 00 \pm 0.05 \%\right.$ ) and the Fe isotope compositions of the major minerals found in BIFs (hematite, magnetite, Fe-carbonate and pyrite) reflect equilibrium fractionation of minerals, a variation in the fluid isotope composition from which the minerals precipitated, and microbial processes (Johnson et al., 2003, 2004; Johnson \& Beard, 2005; Steinhofel et al., 2010).

A recent study focused on the rare earth element and $\mathrm{Fe}$ isotope archive in the iron and microfossil-rich stromatolites of the $1.89 \mathrm{Ga}$ Gunflint and Biwabik iron formations (USA) with the aim of determining the dominant microbes involved in Fe(II) oxidation (Planavsky et al., 2009). These authors point to the predominantly positive $\delta^{56} \mathrm{Fe}$ values in this formation (ranging from -0.66 to $+0.82 \%$ ) as evidence of $\mathrm{Fe}(\mathrm{II})$-oxidizing bacteria, whereas Ce anomalies in these same formations suggest low oxygen conditions during deposition. As a comparison, laboratory experiments designed to define isotopic fractionation by anoxygenic Fe(II)-oxidizing phototrophs in pure culture, as well as enrichment cultures, show that ferric hydroxides are enriched in the heavy isotope by $1.5 \pm 0.2 \%$ relative to $\mathrm{Fe}(\mathrm{II})$ (Croal et al., 2004). This frac- tionation was independent of the rate of the $\mathrm{Fe}(\mathrm{II})$ oxidation by these organisms. Heavier Fe(III) oxyhydroxides were also shown to be produced by microbially catalysed aerobic Fe(II) oxidation at low $\mathrm{pH}$ (Balci et al., 2006), nitratereducing anaerobic $\mathrm{Fe}(\mathrm{II})$ oxidizers (Kappler et al., 2010), aerobic chemical oxidation (Bullen et al., 2001) and UV Fe(II) oxidation (Straton et al., 2006), suggesting that all major processes produce similar $\mathrm{Fe}$ isotope fractionations. On the one hand, the isotopic fractionations reported from modern experiments correlate well with values measured in Archean to early Proterozoic BIFs from the Transvaal Supergroup, South Africa; they have ${ }^{56} \mathrm{Fe} /{ }^{54} \mathrm{Fe}$ values in hematite as high as +0.75 to $+1.0 \%$ o (Johnson et al., 2003) compared with the predicted values for $\mathrm{Fe}$ effused from hydrothermal vents $( \pm 0 \%)$. Consequently, in the case of anoxic Archean oceans, the positive fractionation appears to be consistent with (although not proof of) phototrophic Fe(II) oxidation in the Archean oceans. On the other hand, the similarity in values from anoxygenic phototrophs with those of Fe(III) oxyhydroxides formed by chemical oxidation makes it difficult to distinguish between biotic and abiotic processes (Bullen et al., 2001). Iron isotope fractionation during the oxidation itself is obviously independent of the oxidation mechanism (chemical or biological) because of the very rapid isotopic exchange between aqueous $\mathrm{Fe}^{2+}$ and $\mathrm{Fe}^{3+}$. Therefore, isotopic equilibrium will be reached between reduced and oxidized aqueous species.

\section{Plausibility of anoxygenic photoferrotrophy based on $\mathrm{Fe}$ and $\mathrm{C}$ budget}

Ecophysiological studies of these modern strains of anoxygenic $\mathrm{Fe}(\mathrm{II})$-oxidizing phototrophs have been utilized to test their plausibility as a BIF depositional mechanism, with specific regard to carbon and Fe(III) oxyhydroxide productivity. For example, it has been suggested that communities of $\mathrm{Fe}(\mathrm{II})$-oxidizing phototrophs in the early Archean could have generated up to $1.9 \times 10^{13}$ mol C year $^{-1}$ throughout all oceans (Kharecha et al., 2005). To put this number into context, Canfield (2005) has estimated that the total net primary productivity in the late Archean-Palaeoproterozoic oceans was 1.8 to $5 \cdot 6 \times 10^{14}$ mol C year $^{-1}$.

By modelling the photosynthetic Fe(II) oxidation rates, it has been suggested that such microorganisms could have accounted for all of the 
$\mathrm{Fe}(\mathrm{III})$ initially deposited in primary BIF sediment (Konhauser et al., 2002; Kappler \& Newman, 2004; Kappler et al., 2005). Due to the pigments they utilize (Bchl and carotenoids), anoxygenic phototrophs absorb light over specific wavelengths (Bchla 800 to $880 \mathrm{~nm}$, Bchlb $1020 \mathrm{~nm}$, Bchlc ca $750 \mathrm{~nm}$, carotenoids 360 to $517 \mathrm{~nm})$, many of which (>300 nm and $<600 \mathrm{~nm}$ ) would be filtered out in the first few metres of ocean water. By filtering out the wavelengths $>650 \mathrm{~nm}$, experimental studies have shown that the oxidation rate of these strains was reduced to $20 \%$ of that of the full spectrum, yet that rate still allowed for the oxidation of $0.08 \mathrm{~mm} \mathrm{Fe}(\mathrm{II})$ per day. Based on this reduction in oxidation efficiency due to light filtering, the average cell density in a planktonic population, assumptions of Archean ocean Fe(II) concentrations (ca 0.5 mM; Holland, 1973; Morris, 1993) and the flux of dissolved Fe(II) from the deep oceans, a conservative estimate for the layer thickness of a planktonic population of anoxygenic $\mathrm{Fe}(\mathrm{II})$-oxidizing phototrophs required to oxidize all dissolved Fe(II) present was $17.6 \mathrm{~m}$ (Kappler et al., 2005). With this information, a theoretical amount of Fe(III) oxyhydroxide precipitated by planktonic anoxygenic phototrophs

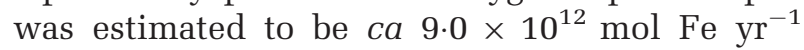
for large basins such the Hamersley in Western Australia (which is $c a 10^{11} \mathrm{~m}^{2}$ ); this value is consistent with calculations based on maximum BIF deposition rates of $1 \mathrm{~mm} \mathrm{yr}^{-1}$ where the amount of iron precipitated annually is $c a$

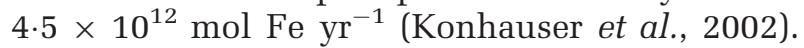
Considering the parameters for a model of Fe(II) oxidation rate, light intensity, substrate concentration and cell numbers, even with reduced efficiency in $\mathrm{Fe}(\mathrm{II})$ oxidation at conservative values of nutrients and light, anoxygenic phototrophs had the potential to play a significant role in BIF deposition.

\section{ROLE OF CELLULAR CARBON IN POST-DEPOSITIONAL ALTERATION}

If a direct biological mechanism was important in the initial process of $\mathrm{Fe}(\mathrm{II})$ oxidation in an Archean ocean water column, it is then expected that biomass settled to the sea floor along with the $\mathrm{Fe}(\mathrm{III})$ minerals (Konhauser et al., 2011a). Yet, BIFs contain very little organic carbon, meaning that the process was either fully abiotic, or biomass was cycled in the water column or bottom sediment via the combined metabolic processes of fermentation and chemoheterotrophy (Konhauser et al., 2005). In the case of the latter, any buried organic carbon would be oxidized and, importantly, any cellular biomass would be destroyed, i.e. no microfossils would be preserved in the Fe-rich layers.

If, as today, the organic carbon was oxidized during burial by either diagenesis or metamorphism, the relevant question is which terminal electron acceptor was present at the sea floor during times of BIF deposition, and at what concentrations? Despite the possibility of a surface water oxic zone generated by cyanobacterial activity by $2.7 \mathrm{Ga}$ (see discussion above), deep waters remained anoxic (Canfield, 1998). In the absence of $\mathrm{O}_{2}$, the fermentation products in the bottom waters and/or shallow sediments would have been oxidized via some other form of anaerobic respiratory process (Rothman et al., 2003). In terms of such pathways, the paucity of $\mathrm{O}_{2}$ would have meant minimal nitrate and sulphate availability; the latter being evident from negligible sulphur isotopic fractionations between sulphide and sulphate minerals during the Archean (Strauss, 2003), and the absence of pyrite in BIFs, except in association with interlayered shaley units (Ewers \& Morris, 1981). The supply of $\mathrm{MnO}_{2}$ was probably also not significant because the concentration of $\mathrm{Mn}$ (II) released in hydrothermal effluent is up to five times lower than that of iron (Campbell et al., 1988). Furthermore, there are presently no known phototrophic Mn(II)-oxidizing bacteria that would allow the formation of significant amounts of $\mathrm{Mn}(\mathrm{IV})$ oxides in the absence of $\mathrm{O}_{2}$. By contrast, however, there was abundant Fe(III) oxyhydroxide deposited as BIFs, and given the presence of partially reduced phases such as magnetite and siderite, a microbial process coupling the oxidation of organic carbon to the reduction of ferric iron producing such reduced iron mineral phases seems very likely (Nealson \& Myers, 1990).

Supporting evidence for an ancient Fe(III) reduction pathway comes from the experimental observations that many deeply branching Archaea (i.e. some of the oldest purported species) are capable of using $\mathrm{H}_{2}$ to reduce Fe(III) to support chemolithoautotrophic growth (Vargas et al., 1998). These organisms can even use quinone moieties as electron shuttles between solid-phase ferric iron-containing minerals and $\mathrm{H}_{2}$, thereby alleviating the need for direct contact between the cell and mineral 
surface (Lovley et al., 2000). Moreover, Fe(III) reduction has been shown to be broadly distributed among several known Proteobacteria genera, suggesting that this form of metabolism became widespread over the course of evolution (Barns \& Nierzwicki-Bauer, 1997).

Evidence of ancient microbial Fe(III) reduction comes from $\mathrm{Fe}$ isotopic ratios in Fe-bearing minerals from Archean sedimentary rocks that closely mimic those observed during modern dissimilatory $\mathrm{Fe}(\mathrm{III})$ reduction. For instance, analyses of magnetite-rich rocks from the $2.9 \mathrm{Ga}$ Rietkuil Formation, Witwatersrand Supergroup, South Africa, revealed $\delta^{56} \mathrm{Fe}$ values as low as $-2.3 \%$ (Yamaguchi et al., 2005), whereas siderite in the 2.5 Ga Dales Gorge Member, Brockman Iron Formation, Western Australia, had $\delta^{56} \mathrm{Fe}$ values as low as $-2 \cdot 3 \%$ (Steinhofel et al., 2010). These negative fractionations are very similar to what might be expected from multiple stages of Fe(III) reduction (Johnson et al., 2004), where each single step during bacterial Fe(III) reduction leads to isotopically light $\left(\delta^{56} \mathrm{Fe}<1.2 \%\right)$ aqueous $\mathrm{Fe}(\mathrm{II})$ relative to the initial ferric hydroxide substrate (Icopini et al., 2004; Crosby et al., 2007). The importance of $\mathrm{Fe}(\mathrm{III})$ reduction in iron fractionation has, however, been challenged by Rouxel et al. (2005). These authors suggested that highly variable, but negative, values in pyrite from black shales $(0.5$ to $-3.5 \%$ ) between $2 \cdot 8 \mathrm{Ga}$ and $2.3 \mathrm{Ga}$ is more likely to reflect the initial deposition of Fe(III) oxides (for example, BIFs) that preferentially removed isotopically heavy ${ }^{56} \mathrm{Fe}$, driving the ocean waters to the negative $\delta^{56} \mathrm{Fe}$ values recorded in pyrite. This interpretation is consistent with the notion that partial biological and abiological processes oxidized the dissolved Fe(II) brought into the shallow waters, but is problematic in light of recent studies showing significant isotopic variations for minerals within close proximity, and thus time of deposition (Johnson et al., 2008). As highlighted by Johnson et al. (2008), the most plausible way of explaining this variation is if the Fe isotopes reflect diagenetic pathways, and not the Fe composition of the bulk sea water.

The fate of cell biomass (organic carbon) deposited with Fe(III) minerals has not yet been shown experimentally. Theoretically, the relation between $\mathrm{Fe}(\mathrm{III})$ and $\mathrm{C}_{\text {org }}$ in the primary sediment would be stoichiometric if the Fe(II) was oxidized to $\mathrm{Fe}(\mathrm{III})$ at the location where biomass was produced, and if the $\mathrm{C}_{\mathrm{org}}$ and $\mathrm{Fe}(\mathrm{III})$ minerals were deposited together, such as in the anoxygenic photoferrotroph model. In this sce- nario, Fe(III) could be completely re-reduced to Fe(II). This could be the case involving anoxygenic photoferrotrophs. However, from experimental studies it is known that some planktonic cells remain in the water column (Konhauser et al., 2005; Miot et al., 2009; Posth et al., 2010) and only a portion of the cells form aggregates with the Fe(III) hydroxide (Fig. 3), which then settle to the sea floor. The reduction of the $\mathrm{Fe}(\mathrm{III})$ mineral and the formation of secondary iron minerals, such as magnetite or siderite, would follow. In such a case, Fe(II) in BIFs can be used as a proxy for deposited $\mathrm{C}_{\text {org }}$ if the $\mathrm{Fe}(\mathrm{II})$ formed by $\mathrm{Fe}(\mathrm{III})$ reduction remains in the BIFs.

In contrast to the anoxygenic phototroph model, if the dissolved Fe(II) was oxidized by an abiotic mechanism, either via the UV-photooxidation mechanism or chemical oxidation by cyanobacterially generated $\mathrm{O}_{2}$ at some distance from the cells (Fig. 2A and B), then the Fe(III) hydroxides produced would be spatially separated from the biomass. This Fe(III) could further react with excess dissolved Fe(II) in the water column forming magnetite [reaction 3], while the cells could be transported away from the shore (Fig. 2B) or be continuously present in the open ocean (Fig. 2C).

$$
\mathrm{Fe}^{2+}+2 \mathrm{Fe}(\mathrm{OH})_{3}+2 \mathrm{OH}^{-} \rightarrow \mathrm{Fe}_{3} \mathrm{O}_{4}+4 \mathrm{H}_{2} \mathrm{O}
$$

As was described for the photoferrotrophs, this scenario could also lead to a partial association of biomass with $\mathrm{Fe}(\mathrm{III})$. In this regard, the presence of cyanobacteria or of photoferrotrophs would be difficult to distinguish based on mineralogical or iron isotope studies, but possibly with the identification of metabolism-specific biomarkers.

To estimate the likelihood and plausible impact of the anoxygenic phototroph scenario, Konhauser et al. (2005) modelled the Archean marine Fe cycle by making two assumptions. Firstly, it was assumed that the bulk of the Fe(II) component in Fe-rich BIF-type macrobands formed diagenetically through biological $\mathrm{Fe}(\mathrm{III})$ reduction, i.e. the magnetite is not primary. Based on a predicted rate of Fe(III) deposition annually $\left(1 \mathrm{~mm} \mathrm{yr}^{-1}\right)$, Konhauser et al. (2005) then quantified how many electrons were needed to generate that amount of magnetite reported in BIFs (one-third of the ferric oxide minerals; Morris, 1993). Secondly, these authors quantified the amount of photosynthetic Fe(II)- 
oxidizer biomass that may have been generated in the photic zone of the water column (based on Kappler et al., 2005) to estimate the amount of Fe recycled prior to burial. The results demonstrated that, under ideal growth conditions, as much as $70 \%$ of the biologically formed Fe(III) could have been recycled back into the water column via fermentation and organic carbon oxidation coupled to microbial Fe(III) reduction. Konhauser et al. (2005) also suggested that some of the biomass may have been ultimately consumed via methanogenesis, i.e. coupling the oxidation of acetate or $\mathrm{H}_{2}$ to methane formation. That hypothesis is to some extent corroborated by the analyses of kerogens (extracted from rocks $2.8 \mathrm{Ga}$ and $2.6 \mathrm{Ga}$ ) with highly negative $\delta^{13} \mathrm{C}$ signatures (between $-40 \%$ and $-60 \%$ ) that possibly formed as the result of methanogenic ${ }^{12} \mathrm{C}$-rich gas production, the incorporation of this methane into the biomass of methanotrophic bacteria and inevitably the preservation of ${ }^{12} \mathrm{C}$-enriched organic matter (Hayes, 1983; Eigenbrode \& Freeman, 2006).

Recent laboratory experiments by the present authors have focused on the influence of temperature $\left(170^{\circ} \mathrm{C}\right)$ and pressure $(1.2 \mathrm{kbar})$ on biogenic $\mathrm{Fe}(\mathrm{III})$ minerals associated with biomass by utilizing chemically synthesized ferrihydrite (as a proxy for biogenic ferric hydroxide) and glucose (as a proxy for biomass) mixtures in lieu of biogenic minerals. When chemically synthesized ferrihydrite was treated alone, it was transformed to hematite via dehydration. Mixtures of ferrihydrite and glucose treated under the same temperature and pressure conditions for just a few days produced not only hematite, but also magnetite and siderite. The presence of a cell biomass proxy in low amounts resulted in the production of hematite and small amounts of magnetite and siderite. When the amount of initial biomass proxy was increased, considerable quantities of magnetite and siderite formed while hematite was no longer detectable. These experiments demonstrate that the amount of biomass deposited to the ocean floor in association with the Fe(III) minerals controls the type of Fe minerals preserved in BIFs over geological time frames at elevated temperature and pressure. This shows that the key minerals found in BIF deposits today can be produced, but that there is also a difference in mineral transformation in abiotic and biotic systems (Walker, 1984; Johnson et al., 2003, 2008; Konhauser et al., 2005; Koehler et al., 2013).

\section{BIOLOGICALLY GENERATED SEDIMENTOLOGICAL FEATURES}

As described above, many BIFs comprise layers containing magnetite and/or hematite, which alternate on the scale of several millimetres and harbour bands of microcrystalline silica. On average, the microbands range from 0.2 to $1.6 \mathrm{~mm}$ in thickness, whereas the total Fe content of the microbands is inversely related to the microband thickness; varying from $30 \% \mathrm{Fe}$ when the microband is $0.3 \mathrm{~mm}$ to $5 \%$ when the thickness is $1.5 \mathrm{~mm}$ (Trendall \& Blockley, 1970). This correlation indicates that the iron content in microbands is constant, whereas variations in the silica content control both the layer thickness and relative iron content (Trendall, 2002). Well-banded iron formations, the typical BIFs, are mostly restricted to Archean and early Palaeoproterozoic sequences (for example, the Transvaal Supergroup, South Africa; Fig. 4A and B). By contrast, large portions of late Palaeoproterozoic iron formations from the Superior and Slave cratons in North America are comprised of sand-sized grains that commonly are cross-bedded and lack the finely laminated textures of BIFs; these shallow-water deposits are generally referred to as granular iron formations (GIFs). These GIFs are typically intercalated with well-laminated BIFs, Fe-rich mudstones, mafic and felsic volcanic rocks, carbonate and sandstone (for example, the Rapitan Formation, Canada; Fig. 4C and D).

The origin of the banding in BIFs remains enigmatic, with two potential end member processes being responsible for their presence. The first assumes that the banding is a primary feature caused by episodic precipitation of the iron layers. The second assumes that the banding was caused by some combination of secondary physical and post-depositional processes. In the case of the former, this can include, for example, BIF precursor sediment being transported to the BIF depositional basin via physical processes, such as density currents (Krapež et al., 2003). In the case of the latter, both allochemical and authigenic BIF sediment would then be subject to chemical and mineralogical transformations arising during burial. The banding thus results when either the Fe(III) was reduced to Fe(II) and the latter diffused out of the sediments, or the silica layers were dissolved and reprecipitated. Although a combination of these processes is likely to have arisen, there still exists a lack of consensus as to which processes were more 

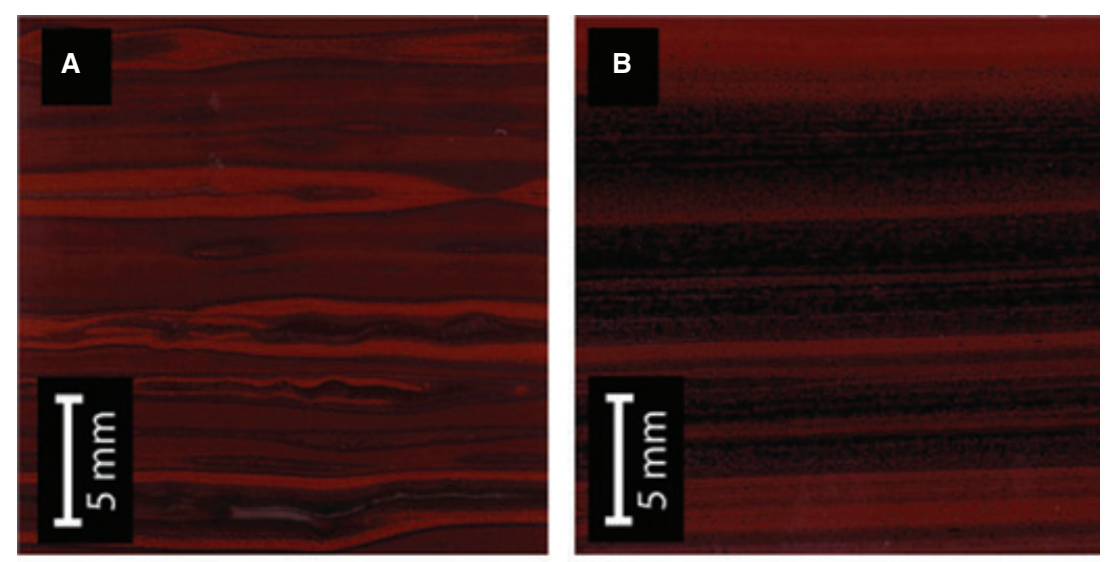

Fig. 4. Thin sections of BIF from the Mamatwan Manganese Mine, Hotazel, Northern Cape Province, South Africa, show jasper and magnetite microbanding. This example demonstrates the variation from thin, alternating lens structures (A) at $83.4 \mathrm{~m}$ depth to well-developed, uninterrupted and alternating fine layers (B) at $87.5 \mathrm{~m}$ depth. In contrast, thin sections from the Rapitan Formation, Canada GIF depict the typical sand-sized grains and discontinuous, uneven layering that suggests stormwave or current influence (C) and (D).
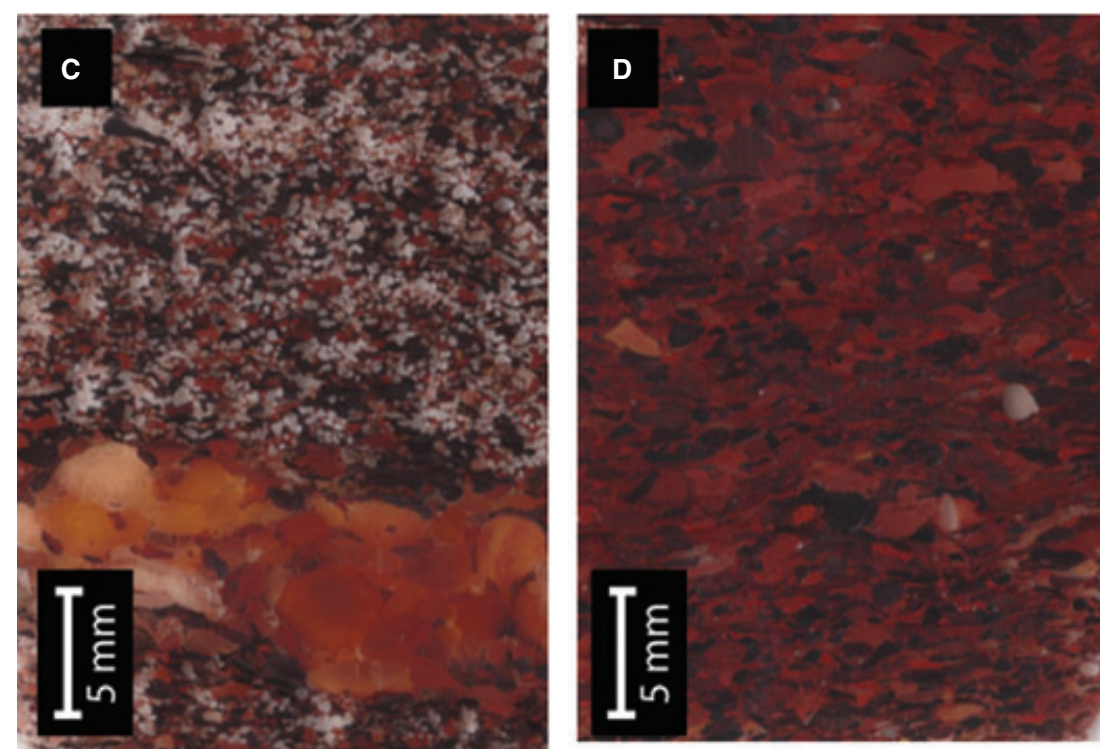

important, and how these processes may have varied from one BIF depositional basin to another.

\section{Primary banding}

Based on microbanding in the $2.48 \mathrm{Ga}$ Dales Gorge Member of Western Australia, that was presumably correlated over $100 \mathrm{~km}$ (Trendall \& Blockley, 1970; Ewers \& Morris, 1981), it was proposed that deposition must have been uniform across the basin. Moreover, given the relatively regular spacing between microbands within some larger mesobands, Trendall \& Blockley (1970) further proposed that each iron and silica-rich microband couplet resulted from one year of chemical precipitation. The term 'varving' is often used to describe these couplets. It should, however, be pointed out that the iron-rich and silica-rich microbands themselves are often comprised of multiple internal laminae, which possibly reflects some form of seasonal variations in terms of deposition. For instance, Morris (1993) suggested that the internal complexity may follow four main stages: (i) during the summer, iron was precipitated in the photic zone, producing the iron-rich laminae; (ii) the now depleted photic zone was replenished several times from the subsurface by storm mixing, leading to additional iron-rich laminae; (iii) in the winter, fewer storms meant less Fe replenishment, while cooling led to silica precipitation from sea water that was already saturated with respect to amorphous silica; and (iv) with the return of the summer, iron was once again precipitated.

The link between BIF deposition and seasonality was later advanced by Posth et al. (2008) who demonstrated how temperature fluctuations in the surface oceans could link the biotic precipitation of $\mathrm{Fe}(\mathrm{III})$ hydroxides by anoxygenic Fe(II)-oxidizing phototrophic bacteria to the 
abiotic precipitation of silica. The precipitation of ferric oxyhydroxides by these bacteria is linked directly to their physiological temperature dependence; within a range, these organisms can precipitate more or less ferric oxyhydroxides. For instance, the bacteria grew most profusely in the temperature range of 20 to $25^{\circ} \mathrm{C}$, with a decrease in growth rates at lower temperatures and a strict upper temperature limit (Posth et al., 2008). By contrast, silica precipitation is abiotically induced by lowering temperature, and increased solubilization of solid-phase silica at higher temperatures. Furthermore, the extent of temperature fluctuations, for which these processes were demonstrated with model organisms, are within the range experienced in the world oceans today over a yearly cycle, meaning that temperature could have been a unifying trigger for $\mathrm{Fe}$ and $\mathrm{Si}$ banding.

Other depositional models for the Dales Gorge Member advocate that BIF deposition took place on the ocean basin floor, beyond the slope environment (Krapež et al., 2003). In this regard, it remains unclear what, if any, role microbes may have played in the initial Fe(III) hydroxide precipitation. The model proposes that the Fe(III)rich sediments accumulated during periods of rising and high sea-level, and presumably were sourced from a submarine hydrothermal system and transported to the BIF depositional basin via deep-sea density currents. The chert layers, by contrast, represent in situ silicification of the existing sediment. The chert defines the top of every depositional sequence by sharp eroded contacts with overlying dolostone or mudrock and gradational contacts into underlying BIFs. The chert units also contain multiple shale relicts, 5 to $10 \mathrm{~cm}$ thick, which indicates that ambient suspension sediments during sediment starvation (i.e. a drop in sea-level) were not BIFs, and that BIF deposition ceased prior to the end of depositional cycles. Similar features are not only preserved throughout all of the Hamersley Province, but they also have been documented in the Transvaal Province (Beukes \& Gutzmer, 2008); it appears to be the common architecture of all deep-water BIFs (Bekker et al., 2010).

\section{Diagenetic banding}

A number of studies have suggested that the fine-scale banding in BIFs is a secondary feature derived during burial diagenesis. One of the first such studies was based largely on the observation of compressed lateral terminations of chert pods (Trendall \& Blockley, 1970). These authors demonstrated that the compressed areas are enriched in iron minerals at the expense mainly of silica and, using this evidence, concluded that all high iron bands, podded or not, represented compression of the primary BIF sediment with vertical escape of silica. The remobilized silica then reprecipitated evenly into overlying pods that are rich in silica. Along similar lines, Simonson (1987) proposed that the chert pods were concretions that formed early via local cementation, followed by differential compaction of the surrounding, less indurated sediments during burial.

More recently, and based instead on facies and sequence-stratigraphic analyses, Krapež et al. (2003) and Pickard et al. (2004) concluded that all chert in BIFs is diagenetic in origin. Moreover, these authors concluded that chert mesobands are siliceous equivalents of modernday sea floor hardgrounds, in which silica replaced precursor sediment at or below the sediment-water interface. Three-dimensional and micro-scale lenticularity of chert and relics of precursor sediment within lamina sets and discontinuous bands, as well as erosion surfaces on bedded cherts, show that chert has a replacement origin and formed during early diagenesis, prior to compaction. As discussed above, the iron layers, by contrast, represent re-suspended Fe(III) hydroxide-rich sediments that were carried into the depositional basin via density currents and then subject to post-depositional processes (Krapež et al., 2003).

Other studies have put forward the possibility that it was the iron that was selectively mobilized during diagenesis. Based on the earlier discovery that some anaerobic heterotrophs could grow by coupling the oxidation of organic matter to the reduction of $\mathrm{Fe}$ (III) hydroxides (Lovley \& Phillips, 1988), Nealson \& Myers (1990) subsequently proposed that such bacteria could provide a mechanism by which iron-poor layers could be generated during diagenesis; the ironrich layers represent sediment buried in which molar Fe : C ratios exceeded unity and all the biomass was oxidized. Coupling the reduction of $\mathrm{Fe}$ (III) minerals to the oxidation of organic matter not only explains the low content of organic carbon in the BIFs via the consumption of carbon $(<0.5 \%$; Gole \& Klein, 1981), but also explains the abundance of light carbon isotopic signatures associated with the interlayered 
carbonate minerals (Perry et al., 1973; Walker, 1984; Baur et al., 1985).

\section{CONCLUSIONS}

Understanding the mechanism(s) underpinning banded iron formation (BIF) deposition would offer significant insights into some of the biogeochemical processes that took place on the early Earth. The first suggestions of a microbial role were postulated over 40 years ago (Cloud, 1965). At present, there is still indirect evidence of a microbial mechanism driven by either anoxygenic Fe(II)-oxidizing photosynthesis or cyanobacterially driven $\mathrm{O}_{2}$ production. Moreover, the complexity of BIF deposition, on temporal and spatial scales, makes it possible that multiple mechanisms aided BIF deposition, depending on the ocean and atmospheric redox state, as well as on the local geochemical and microbiological conditions. One could imagine a scenario with anoxygenic phototrophs being mainly responsible for the deposition of the BIFs in low $\mathrm{O}_{2}$ oceans prior to the Great Oxidation Event (GOE). After the emergence of cyanobacteria, it has been suggested that $\mathrm{O}_{2}$ producing cyanobacteria could have helped drive the abiotic oxidation of Fe(II), whereas anoxygenic phototrophs carried out $\mathrm{Fe}(\mathrm{II})$ oxidation in an anoxic niche (Kappler et al., 2005). In order to understand BIFs and the biogeosphere in which they were deposited, as well as to be able to interpret them as an archive of Earth history, it is necessary to take a holistic approach - integrating new methods for biomarker and stable isotope analyses, and also keeping this in context with mineralogical examinations and ecophysiological studies with modern analogue micro-organisms.

\section{ACKNOWLEDGEMENTS}

We thank Nicolas Beukes for his advice on South African BIFs, as well as his guidance in sample collection. Gert van der Linde of the Hotazel Manganese Mines, Hotazel, South Africa, provided BIF samples. We also thank Claus Burkhardt and Sebastian Schädler for the preparation of SEM images, which was carried out at the Natural and Medical Sciences Institute at the University of Tuebingen (NMI). This work was supported by an Emmy-Noether fellowship and a research grant from the German Research Foundation (DFG) made to AK (KA
1736/2-1, 2-2 and 4-1), a research grant from the German Research Foundation (DFG) made to N.P. (PO-1624/1-1, 2-1), and a Natural Sciences and Engineering Research Council award to KOK. We thank Clark Johnson, Phil Fralick, Nora Noffke and an anonymous reviewer for their helpful comments, which greatly improved the quality of the manuscript.

\section{REFERENCES}

Altermann, W. and Kazmierczak, J. (2003) Archean microfossils: a reappraisal of early life on Earth. Res. Microbiol., 154, 611-617.

Altermann, W. and Schopf, J.W. (1995) Microfossils from the Neoarchean Campbell Group, Griqualand West Sequence of the Transvaal Supergroup, and their paleoenvironmental and evolutionary implications. Precambrian Res., 75, 65-90.

Anbar, A.D., Duan, Y., Lyons, T.W., Arnold, G.L., Kendall, B., Creaser, R.A., Kaufman, A.J., Gordon, G.W., Scott, C., Garvin, J. and Buick, R. (2007) A whiff of oxygen before the great oxidation event? Science, 317, 1903-1906.

Balci, N., Bullen, T.D., Witte-Lien, K., Shanks, W.C., Motelica, M. and Mandernack, K.W. (2006) Iron isotope fractionation during microbially stimulated Fe(II) oxidation and Fe(III) precipitation. Geochim. Cosmochim. Acta, 70, 622-639.

Barns, S.M. and Nierzwicki-Bauer, S.A. (1997) Microbial diversity in ocean, surface and subsurface environments. In: Geomicrobiology: Interactions Between Microbes and Minerals (Eds J.F. Banfield and K.H. Nealson), pp. 35-79. Mineralogical Society of America, Washington, DC.

Bau, M. and Möller, P. (1993) Rare earth element systematics of the chemically precipitated component in Early Precambrian iron-formations and the evolution of the terrestrial atmosphere-hydrosphere-lithosphere system. Geochim. Cosmochim. Acta, 57, 2239-2249.

Baur, M.E., Hayes, J.M., Studley, S.A. and Walter, M.R. (1985) Millimeter-scale variations of stable isotope abundances in carbonates from banded iron formations in the Hamersley Group of Western Australia. Econ. Geol., 80, 270-282.

Bekker, A., Holland, H.D., Wang, P.-L., Rumble, D., III, Stein, H.J., Hannah, J.L., Coetzee, L.L. and Beukes, N.J. (2004) Dating the rise of atmospheric oxygen. Nature, 427, 117-120.

Bekker, A., Slack, J.F., Planavsky, N., Krapež, B., Hofmann, A., Konhauser, K.O. and Rouxel, O.J. (2010) Iron formation: a sedimentary product of the complex interplay among mantle, tectonic, and biospheric processes. Econ. Geol., 105, 467-508.

Beukes, N.J. (1973) Precambrian iron-formations of Southern Africa. Econ. Geol., 68, 960-1004.

Beukes, N.J. (1984) Sedimentology of the Kuruman and Griquatown Iron-Formations, Transvaal Supergroup, Griqualand West, South Africa. Precambrian Res., 24(1), 47-84.

Beukes, N.J. and Gutzmer, J. (2008) Origin and paleoenvironmental significance of major iron formations at the Archean-Paleoproterozoic boundary. Rev. Econ. Geol., 15, $5-47$. 
Bosak, T., Greene, S.E. and Newman, D.K. (2007) A possible role for anoxygenic photosynthetic microbes in the formation of ancient stromatolites. Geobiology, 5, 119-126.

Bosak, T., Liang, B., Sim, M.S. and Petroff, A.P. (2009) Morphological record of oxygenic photosynthesis in conical stromatolites. Proc. Natl Acad. Sci. USA, 106(27), 10939-10943.

Brasier, M.D., Green, O.R., Jephcoat, A.P., Kleppe, A.K., Van Kranendonk, M.J., Lindsay, J.F., Steele, A. and Grassineau, N.V. (2002) Questioning the evidence for Earth's oldest fossils. Nature, 416, 76-81.

Brasier, M.D., Green, P.R., Lindsay, J.F., McLoughlin, N., Steele, A. and Stoakes, C. (2005) Critical testing of Earth's oldest putative fossil assemblage from the $\sim 3.5$ Apex chert, Chinaman Creek, Western Australia. Precambrian Res., 140, 55-105.

Braterman, P.S., Cairns-Smith, A.G. and Sloper, R.W. (1983) Photo-oxidation of hydrated $\mathrm{Fe}^{2+}$ - significance for banded iron formations. Nature, 303, 163-164.

Brocks, J.J. (2005) Biomarker evidence for green and purple sulphur bacteria in a stratified Palaeoproterozoic sea. Nature, 437, 866-870.

Brocks, J.J., Logan, G.A., Buick, R. and Summons, R.E. (1999) Archean molecular fossils and the early rise of eukaryotes. Science, 285, 1033-1036.

Buick, R. (1988) Carbonaceous filaments from North Pole, West Australia: are they fossil bacteria in Archean stromatolites? A reply. Precambrian Res., 39, 311-317.

Buick, R. (1992) The antiquity of oxygenic photosynthesis: evidence for stromatolites in sulphate-deficient Archaean lakes. Science, 255, 74-77.

Buick, R. (2008) When did oxygenic photosynthesis evolve? Philos. Trans. R. Soc. Lond. B: Biol. Sci., 363, 2731-2743.

Bullen, T.D., White, A.F., Childs, C.W., Vivit, D.V. and Schulz, M.J. (2001) Demonstration of significant abiotic iron isotope fractionation in nature. Geology, 29(8), 699-702.

Burns, B.P., Goh, F., Allen, M. and Neilan, B.A. (2004) Microbial diversity of extant stromatolites in the hypersaline marine environment of Shark Bay, Australia. Environ. Microbiol., 6, 1096-1101.

Burns, B.P., Anitori, R., Butterworth, P., Henneberger, R., Goh, F., Allen, M.A., Ibañez-Peral, R., Bergquist, P.L., Walter, M.R. and Neilan, B.A. (2009) Modern analogues and the early history of microbial life. Precambrian Res., 173, 10-18.

Cairns-Smith, A.G. (1978) Precambrian solution photochemistry, inverse segregation, and banded iron formations. Nature, 276, 807-808.

Campbell, A.C., Palmer, M.R., Klinkhammer, G.P., Bowers, T.S., Edmond, J.M., Lawrence, J.R., Casey, J.F., Thompson, G., Humphris, S., Rona, P. and Karson, J.A. (1988) Chemistry of hot springs on the Mid-Atlantic Ridge. Nature, 335, 514-519.

Canfield, D.E. (1998) A new model for Proterozoic ocean chemistry. Nature, 396, 450-453.

Canfield, D.E. (2005) The early history of atmospheric oxygen: homage to Robert M. Garrels. Annu. Rev. Earth Planet. Sci., 33, 1-36.

Canfield, D.E., Habicht, K.S. and Thamdrup, B. (2000) The Archean sulfur cycle and the early history of atmospheric oxygen. Science, 288, 658-661.
Cloud, P. (1965) Significance of the Gunflint (Precambrian) microflora. Science, 148, 27-35.

Cloud, P. (1969) Atmospheric and hydrospheric evolution on the primitive Earth. Science, 160, 729-736.

Cloud, P. (1973) Paleoecological significance of the banded iron-formation. Econ. Geol., 68, 1135-1143.

Croal, L.R., Johnson, C.M., Beard, B.L. and Newman, D.K. (2004) Iron isotope fractionation by $\mathrm{Fe}(\mathrm{II})$-oxidizing photoautotrophic bacteria. Geochim. Cosmochim. Acta, 68, 1227-1242.

Croal, L.R., Jiao, Y., Kappler, A. and Newman, D.K. (2009) Phototrophic Fe(II) oxidation in an atmosphere of $\mathrm{H}_{2}$ : implications for Archean banded iron formations. Geobiology, 7(1), 21-24

Crosby, H.A., Roden, E.E., Johnson, C.M. and Beard, B.L. (2007) The mechanisms of iron isotope fractionation produced during dissimilatory $\mathrm{Fe}(\mathrm{III})$ reduction by Shewanella putrefaciens and Geobacter sulfurreducens. Geobiology, 5, 169-189.

Dimroth, E. and Chauvel, J.J. (1973) Petrography of the Sokoman iron formation in part of the central Labrador trough, Quebec, Canada. Geol. Soc. Am. Bull., 84, 111134.

Ehrenreich, A. and Widdel, F. (1994) Anaerobic oxidation of ferrous iron by purple bacteria, a new-type of phototrophic metabolism. Appl. Environ. Microbiol., 60, 4517-4526.

Eickhoff, M., Birgel, D., Talbot, H.M., Peckmann, J. and Kappler, A. (2013) Oxidation of Fe(II) leads to increased C-2 methylation of pentacyclic triterpenoids in the anoxygenic phototrophic bacterium Rhodopseudomonas palustris strain TIE-1. Geobiology, 11, 268-278.

Eigenbrode, J.L. and Freeman, K.H. (2006) Late Archean rise of aerobic microbial ecosystems. Proc. Natl Acad. Sci. USA, 103(43), 15759-15764.

Eigenbrode, J.L., Freeman, K.H. and Summons, R.E. (2008) Methylhopane biomarker hydrocarbons in Hamersley Province sediments provide evidence for Neoarchean aerobiosis. Earth Planet. Sci. Lett., 273, 323-331.

Ewers, W.E. and Morris, R.C. (1981) Studies of the Dales Gorge Member of the Brockman iron formation, Western Australia. Econ. Geol., 76, 1929-1953.

Farquhar, J., Bao, H. and Thiemens, M. (2000) Atmospheric influence of Earth's earliest sulfur cycle. Science, 289, 756-758.

Farquhar, J.F., Zerkle, A.K. and Bekker, A. (2011) Geological constraints on the origin of oxygenic photosynthesis. Photosynth. Res., 107, 11-36.

Fischer, W.W. and Pearson, A. (2007) Hypotheses for the origin and early evolution of triterpenoid cyclases. Geobiology, 5, 19-34.

Fischer, W.W., Summons, R.E. and Pearson, A. (2005) Targeted genomic detection of biosynthetic pathways: anaerobic production of hopanoid biomarkers by a common sedimentary microbe. Geobiology, 3, 33-40.

Fischer, W.W., Schroeder, S., Lacassie, J.P., Beukes, N.J., Goldberg, T., Strauss, H., Horstmann, U.E., Schrag, D.P. and Knoll, A.H. (2009) Isotopic constraints on the late Archean carbon cycle from the Transvaal Supergroup along the western margin of the Kaapvaal Craton, South Africa. Precambrian Res., 169, 15-27.

Fralick, P. and Pufahl, P.K. (2006) Iron formation in neoarchean deltaic successions and the microbially mediated deposition of transgressive systems tracts. J. Sed. Res., 76, 1057-1066. 
Frei, R., Gaucher, C., Poulton, S.W. and Canfield, D.E. (2009) Fluctuations in Precambrian atmospheric oxygenation recorded by chromium isotopes. Nature, 461, 250-254.

Garcia-Ruiz, J.M., Hyde, S.T., Carnerup, A.M., Christy, A.G., Van Kranendonk, M.J. and Welham, N.J. (2003) Self-assembled silica-carbonate structures and detection of ancient microfossils. Science, 302, 1194-1197.

Garrels, R.M., Perry, E.A., Jr and MacKenzie, F.T. (1973) Genesis of Precambrian iron-formations and the development of atmospheric oxygen. Econ. Geol., 68, 1173-1179.

Godfrey, L.V. and Falkowski, P.G. (2009) The cycling and redox state of nitrogen in the Archaean ocean. Nature Geosci., 2, 725-729.

Gole, M.J. and Klein, C. (1981) Banded Iron Formations through much of Precambrian time. J. Geol., 89, 169-183.

Grotzinger, J.P. and Knoll, A.H. (1999) Stromatolites in Precambrian carbonates: evolutionary mileposts or environmental dipsticks? Annu. Rev. Earth Planet. Sci., 27, 313-358.

Grotzinger, J.P. and Rothman, D.H. (1996) An abiotic model for stromatolite morphogenesis. Nature, 383, 423-425.

Hamade, T., Konhauser, K.O., Raiswell, R., Goldsmith, S. and Morris, R.C. (2003) Using Ge/Si ratios to decouple iron and silica fluxes in Precambrian banded iron formations. Geology, 31, 35-38.

Han, T.-M. (1966) Textural relations of hematite and magnetite in some Precambrian metamorphosed oxide iron-formations. Econ. Geol., 61, 1306-1310.

Han, T.-M. (1978) Microstructures of magnetite as guides to its origin in some Precambrian iron-formations. Fortschr. Mineral., 56(1), 105-142.

Hartman, H. (1984) The evolution of photosynthesis and microbial mats: a speculation on banded iron formations. In: Microbial Mats: Stromatolites (Eds Y. Cohen, R.W. Castenholz and H.O. Halvorson), pp. 451-453. Alan Liss, New York.

Härtner, T., Straub, K.L. and Kannenberg, E. (2005) Occurrence of hopanoid lipids in anaerobic Geobacter species. FEMS Microbiol. Lett., 243, 59-64.

Hayes, J.M. (1983) Geochemical evidence bearing on the origin of aerobiosis, a speculative hypothesis. In: Earth's Earliest Biosphere, Its Origins and Evolution (Ed. J.W. Schopf), pp. 291-301. Princeton University Press, Princeton, NJ.

Hegler, F., Posth, N.R., Jiang, J. and Kappler, A. (2008) Physiology of phototrophic iron(II)-oxidizing bacteriaimplications for modern and ancient environments. FEMS Microbiol. Ecol., 66(2), 250-260.

Heising, S. and Schink, B. (1998) Phototrophic oxidation of ferrous iron by a Rhodomicrobium vannielii strain. Microbiology, 144, 2263-2269.

Heising, S., Richter, L., Ludwig, W. and Schink, B. (1999) Chlorobium ferrooxidans sp. nov., a phototrophic green sulfur bacterium that oxidizes ferrous iron in coculture with a Geospirillum sp. strain. Arch. Microbiol., 172, 116-124.

Hoefs, J. (1997) Stable Isotope Geochemistry, 4th edn. Springer Verlag, Berlin Heidelberg, $201 \mathrm{pp}$.

Holland, H.D. (1973) The oceans: a possible source of iron in iron-formations. Econ. Geol., 68, 1169-1172.

Holm, N.G. (1989) The ${ }^{13} \mathrm{C} /{ }^{12} \mathrm{C}$ ratios of siderite and organic matter of a modern metalliferous hydrothermal sediment and their implications for banded iron formations. Chem. Geol., 77, 41-45.
Icopini, G.A., Anbar, A.D., Ruebush, S.R., Tien, M. and Brantley, S.L. (2004) Iron isotope fractionation during microbial reduction of iron. Geology, 32(3), 205-208.

Isley, A.E. (1995) Hydrothermal plumes and the delivery of iron to banded iron formation. J. Geol., 103, 169-185.

Isley, A.E. and Abbot, D.H. (1999) Plume-related mafic volcanism and the deposition of banded iron formation. J. Geophy. Res., 104, 15461-15477.

Jacobsen, S.B. and Pimentel-Klose, M.R. (1988) A Nd isotopic study of the Hamersley and Michipicoten banded iron formations: the source of REE and Fe in Archean oceans. Earth Planet. Sci. Lett., 87, 29-44.

James, H.L. (1954) Sedimentary facies of iron-formation. Econ. Geol., 49(3), 236-294.

Jiao, Y., Kappler, A., Croal, L.R. and Newman, D.K. (2005) Isolation and characterization of a genetically traceable photoautotrophic Fe(II)-oxidizing bacterium, Rhodopseudomonas palustris strain Tie-1. Appl. Environ. Microbiol., 71, 4487-4496.

Johnson, C.M. and Beard, B.L. (2005) Biogeochemical cycling of iron isotopes. Science, 309, 1025-1027.

Johnson, C.M., Beard, B.L., Beukes, N.J., Klein, C. and $\mathbf{O}^{\prime}$ Leary, J.M. (2003) Ancient geochemical cycling in the Earth as inferred from Fe isotope studies of banded iron formations from the Transvaal craton. Contrib. Mineral. Petrol., 144, 523-547.

Johnson, C.M., Beard, B.L., Roden, E.E., Newman, D.K. and Nealson, K.H. (2004) Isotopic constraints on biogeochemical cycling of Fe. Rev. Mineral. Geochem., 55, 359-408.

Johnson, C.M., Roden, E.E., Welch, S.A. and Beard, B.L. (2005) Experimental constraints on Fe isotope fractionation during magnetite and Fe carbonate formation coupled to dissimilatory hydrous ferric oxide reduction. Geochim. Cosmochim. Acta, 69, 963-993.

Johnson, C.M., Beard, B.L., Klein, C., Beukes, N.J. and Roden, E.E. (2008) Iron isotopes constrain biologic and abiologic processes in banded iron formation genesis. Geochim. Cosmochim. Acta, 72, 151-169.

Kappler, A. and Newman, D.K. (2004) Formation of Fe(III) minerals by $\mathrm{Fe}(\mathrm{II})$ oxidizing photoautotrophic bacteria. Geochim. Cosmochim. Acta, 68, 1217-1226.

Kappler, A., Pasquero, C., Konhauser, K.O. and Newman, D.K. (2005) Deposition of banded iron formations by anoxygenic phototrophic Fe(II)-oxidizing bacteria. Geology, 33, 865-868.

Kappler, A., Johnson, C.M., Crosby, H.A., Beard, B.L. and Newman, D.K. (2010) Evidence for equilibrium iron isotope fractionation by nitrate-reducing iron(II)-oxidizing bacteria. Geochim. Cosmochim. Acta, 74, 2826-2842.

Kaufman, A.J., Johnston, D.T., Farquhar, J., Masterson, A.L., Lyons, T.W., Bates, S., Anbar, A.D., Arnold, G.L., Garvin, J. and Buick, R. (2007) Late Archean biospheric oxygenation and atmospheric evolution. Science, 317, 1900-1903.

Kendall, B., Reinhard, C.T., Lyons, T.W., Kaufman, A.J., Poulton, S.W. and Anbar, A.D. (2010) Pervasive oxygenation along late Archaean ocean margins. Nature Geosci., 3, 647-652.

Kharecha, P., Kasting, J. and Siefert, J. (2005) A coupled atmosphere-ecosystem model of the early Archean Earth. Geobiology, 3, 53-76.

Klein, C. (2005) Some Precambrian Banded Iron Formations (BIFs) from around the world: their age, geologic setting, 
mineralogy, metamorphism, geochemistry, and origin. Am. Mineral., 90, 1473-1499.

Klein, C. and Beukes, N.J. (1992) Time Distribution, Stratigraphy, and Sedimentologic Setting, and Geochemistry of Precambrian Iron-Formations. In: The Proterozoic Biosphere: A Multidisciplinary Study (Eds J.W. Schop and C. Klein), pp. 139-146. Press syndicate of the University of Cambridge, Cambridge.

Koehler, I., Papineau, D., Konhauser, K.O. and Kappler, A. (2013) Biological carbon precursor to diagenetic siderite spherulites in banded iron formations. Nature Commun., doi:10.1038/ncomms2770.

Konhauser, K.O. (2007) Introduction to Geomicrobiology. Blackwell, Oxford, 425 pp.

Konhauser, K., Hamade, T., Raiswell, R., Morris, R.C., Ferris, F.G., Southam, G. and Canfield, D.E. (2002) Could bacteria have formed the Precambrian banded iron formations? Geology, 30, 1079-1082.

Konhauser, K., Newman, D.K. and Kappler, A. (2005) The potential significance of microbial Fe(III) reduction during deposition of Precambrian banded iron formations. Geobiology, 3, 167-177.

Konhauser, K.O., Amskold, L., Lalonde, S.V., Posth, N.R., Kappler, A. and Anbar, A. (2007a) Decoupling photochemical Fe(II) oxidation from shallow-water deposition. Earth Planet. Sci. Lett., 258, 87-100.

Konhauser, K.O., Lalonde, S., Amskold, L. and Holland, H.D. (2007b) Was there really an Archean phosphate crisis? Science, 315, 1234.

Konhauser, K.O., Kappler, A. and Roden, E.E. (2011a) Iron in microbial metabolism. Elements, 7, 89-93.

Konhauser, K.O., Lalonde, S.V., Planavsky, N., Pecoits, E., Lyons, T., Mojzsis, S., Rouxel, O.J., Barley, M., Rosiere, C., Fralick, P.W., Kump, L.R. and Bekker, A. (2011b) Chromium enrichment in iron formations record Earth's first acid rock drainage during the Great Oxidation Event. Nature, 478, 369-373.

Krapež, B., Barley, M.E. and Pickard, A.L. (2003) Hydrothermal and resedimented origins of the precursor sediments to banded iron formation: sedimentological evidence from the Early Paleoproterozoic Brockman Supersequence of Western Australia. Sedimentology, 50, 979-1011.

Kump, L. and Barley, M.E. (2007) Increased subaerial volcanism and the rise of atmospheric oxygen 2.5 billion years ago. Nature, 448, 1033-1036.

Kump, L.R. and Holland, H.D. (1992) Iron in Precambrian rocks: implications for the global oxygen budget of the ancient Earth. Geochim. Cosmochim. Acta, 56, 3217-3223.

Li, J.L., Konhauser, K.O., Cole, D.R. and Phelps, T.J. (2011) Mineral ecophysiological data provide growing evidence for microbial activity in banded-iron formations. Geology, 39, 707-710.

Lovley, D.R. and Phillips, E.J.P. (1988) Novel mode of microbial energy metabolism: organic carbon oxidation coupled to dissimilatory reduction of iron or manganese. Appl. Environ. Microbiol., 54, 1472-1480.

Lovley, D.R., Kashefi, K., Vargas, M., Tor, J.M. and BluntHarris, E.L. (2000) Reduction of humic substances and Fe (III) by hyperthermophilic microorganisms. Chem. Geol., 169, 289-298.

Maliva, R.G., Knoll, A.H. and Simonson, B.M. (2005) Secular change in the Precambrian silica cycle: insights from chert petrology. Geol. Soc. Am. Bull., 117, 835-845.

Manske, A.K., Glaeser, J., Kuypers, M.A.M. and Overmann, J. (2005) Physiology and phylogeny of green sulfur bacteria forming a monospecific phototrophic assemblage at a depth of 100 meters in the Black Sea. Appl. Environ. Microbiol., 71, 8049-8060.

Marshall, C.P., Emry, J.R. and Olcott Marshall, A. (2011) Haematite pseudomicrofossils present in the 3.5-billionyear-old Apex chert. Nature Geosci., 4, 240-243.

McLoughlin, N., Wilson, L.A. and Brasier, M.D. (2008) Growth of synthetic stromatolites and wrinkle structures in the absence of microbes - implications for the early fossil record. Geobiology, 6, 95-105.

Miot, J., Benzerara, K., Obst, M., Kappler, A., Hegler, F., Schäedler, S., Bouchez, C., Guyot, F. and Morin, G. (2009) Extracellular iron biomineralization by photoautotrophic iron-oxidizing bacteria. Appl. Environ. Microbiol., 75, 5586-5591.

Mojzsis, S.J., Coath, C.D., Greenwood, J.P., McKeegan, K.D. and Harrison, T.M. (2003) Mass-independent isotope effects in Archean (2.5 to $3.8 \mathrm{Ga}$ ) sedimentary sulfides determined by ion microprobe analysis. Geochim. Cosmochim. Acta, 67, 1635-1658.

Morris, R.C. (1993) Genetic modelling for banded ironformation of the Hamersley Group, Pilbara Craton, Western Australia. Precambrian Res., 60, 243-286.

Morris, R.C. and Horwitz, R.C. (1983) The origin of the ironformation-rich Hamersley Group of Western Australia Deposition on a platform. Precambrian Res., 21, 273-297.

Nealson, K. H. and Myers, C. R. (1990) Iron reduction by bacteria: a potential role in the genesis of banded iron formations. Am. J. Sci., 290-A, 35-45.

Noffke, N., Beukes, N., Bower, D., Hazen, R.M. and Swift, D.J.P. (2008) An actualistic perspective into Archean worlds - (cyano)bacterially induced sedimentary structures in the siliciclastic Nhlazatse Section, $2.9 \mathrm{Ga}$ Pongola Supergroup, South Africa. Geobiology, 6, 5-20.

Olson, J.M. and Blankenship, R.E. (2004) Thinking about the evolution of photosynthesis. Photosynth. Res., 80, 373386.

Overmann, J., Cypionka, H. and Pfennig, N. (1992) An extremely low light adapted phototrophic sulfur bacterium from the Black Sea. Limnol. Oceanogr., 37, 150-155.

Papineau, D., Walker, J.J., Mojzsis, S.J. and Pace, N.R. (2005) Composition and structure of Microbial communities from stromatolites of Hamelin pool in Shark Bay, Western Australia. Appl. Environ. Microbiol., 71(8), 4822-4832.

Pasteris, J.D. and Wopenka, B. (2003) Necessary, but not sufficient Raman identification of disordered carbon as a signature of ancient life. Astrobiology, 3, 727-738.

Pavlov, A.A. and Kasting, J.F. (2002) Mass-independent fractionation of sulfur isotopes in Archean sediments: strong evidence for an anoxic Archean atmosphere. Astrobiology, 2, 27-41.

Perry, E.C., Tan, F.C. and Morey, G.B. (1973) Geology and stable isotope geochemistry of the Biwabik Iron Formation, northern Minnesota. Econ. Geol., 68, 1110-1125.

Phoenix, V.R., Konhauser, K.O., Adams, D.G. and Bottrell, S.H. (2001) Role of biomineralization as an ultraviolet shield: implications for Archean life. Geology, 29, 823-826.

Pickard, A.L., Barley, M.E. and Krapež, B. (2004) Deepmarine depositional setting of banded iron formation: sedimentological evidence from interbedded clastic sedimentary rocks in the early Palaeoproterozoic Dales Gorge Member of Western Australia. Sed. Geol., 170, $37-62$. 
Pierson, B.K. (1994) The emergence, diversification, and role of photosynthetic eubacteria. In: Early Life on Earth (Ed. S. Bengtson), pp. 161-180. Nobel Symposium No. 84 held at Björkborn, Sweden, 16-21 May 1992.

Planavsky, N., Rouxel, O., Bekker, A., Shapiro, R., Fralick, P. and Knudsen, A. (2009) Iron-oxidizing microbial ecosystems thrived in late Paleoproterozoic redoxstratified oceans. Earth Planet. Sci. Lett., 286(1-2), 230-242.

Posth, N.R., Hegler, F., Konhauser, K.O. and Kappler, A. (2008) Alternating $\mathrm{Si}$ and $\mathrm{Fe}$ deposition caused by temperature fluctuations in Precambrian oceans. Nature Geosci., 1(10), 703-708.

Posth, N.R., Huelin, S., Konhauser, K.O. and Kappler, A. (2010) Size, density and composition of cell-mineral aggregates formed during anoxygenic phototrophic Fe(II) oxidation: impact on modern and ancient environments. Geochim. Cosmochim. Acta, 74, 3476-3493.

Rashby, S.E., Sessions, A.L., Summons, R.E. and Newman, D.K. (2007) Biosynthesis of 2-methylbacteriohopanepolyols by an anoxygenic phototroph. Proc. Natl Acad. Sci. USA, 104(38), 15099-15104.

Rasmussen, B. and Buick, R. (1999) Redox state of the Archean atmosphere: evidence from detrital heavy metals in ca. 3250-2750 Ma sandstones from the Pilbara Craton, Australia. Geology, 27, 115-118.

Rasmussen, B., Fletcher, I.R., Brocks, J.J. and Kilburn, M.R. (2008) Reassessing the first appearance of eukaryotes and cyanobacteria. Nature, 455, 1101-1104.

Raymond, J. and Blankenship, R.E. (2004) Biosynthetic pathways, gene replacement and the antiquity of life. Geobiology, 2, 199-203.

Reinhard, C.T., Raiswell, R., Scott, C., Anbar, A.D. and Lyons, T.W. (2009) A Late Archean sulfidic sea stimulated by early oxidative weathering of the continents. Science, 326, 713-716.

Rothman, D.H., Hayes, J.M. and Summons, R.E. (2003) Dynamics of the Neoproterozoic carbon cycle. Proc. Natl Acad. Sci. USA, 100, 8124-8129.

Rouxel, O.J., Bekker, A. and Edwards, K.J. (2005) Iron isotope constraints on the Archean and Paleoproterozoic. Science, 307, 1088-1091.

Rye, R. and Holland, H.D. (1998) Paleosols and the evolution of atmospheric oxygen: a critical review. Am. J. Sci., 298, 621-672.

Schaedler, S., Burkhardt, C., Hegler, F., Straub, K.L., Miot, J., Benzerara, K. and Kappler, A. (2009) Formation of celliron-mineral aggregates by phototrophic and nitratereducing anaerobic Fe(II)-oxidizing bacteria. Geomicrob. J., 26, 93-103.

Schidlowski, M. (2000) Carbon isotopes and microbial sediments. In: Microbial Sediments (Eds R. Riding and S.M. Awramik), pp. 84-95. Springer Verlag, Berlin.

Schopf, J.W. (1993) Microfossils of the Early Archean Apex chert: new evidence of the antiquity of life. Science, 260, 640-646.

Schopf, J.W. and Kudryavtsev, A.B. (2009) Confocal laser scanning microscopy and Raman imagery of ancient microscopic fossils. Precambrian Res., 173, 39-49.

Schopf, J.W. and Packer, B.M. (1987) Early Archean (3.3billion to 3.5-billion-year-old) microfossils from Warrawoona Group, Australia. Science, 237, 70-73.

Schopf, J.W., Kudryavtsev, A.B., Agresti, D.G., Wdowiak, T.J. and Czaja, A.D. (2002) Laser-Raman imagery of Earth's earliest fossils. Nature, 416, 73-76.
Schopf, J.W., Kudryavtsev, A.B., Czaja, A.D. and Tripathi, A.B. (2007) Evidence of Archean life: stromatolites and microfossils. Precambrian Res., 158, 141-155.

Siever, R. (1992) The silica cycle in the Precambrian. Geochim. Cosmochim. Acta, 56, 3265-3272.

Simonson, B.M. (1987) Early silica cementation and subsequent diagenesis in arenites from four early Proterozoic iron formations of North America. J. Sed. Petrol., 57, 494-511.

Steinhofel, G., von Blackenburg, F., Horn, I., Konhauser, K.O., Beukes, N. and Gutzmer, J. (2010) Deciphering formation processes of banded iron formations from the Transvaal and the Hamersley Sequence by combined Si and $\mathrm{Fe}$ isotope analysis using UV femtosecond laser ablation. Geochim. Cosmochim. Acta, 74, 2677-2696.

Straton, S., Amskold, L., Anbar, A. and Konhauser, K.O. (2006) Iron Isotope Fractionation During Fe(II) PhotoOxidation. Astrobiology Science Conference 4, Washington, DC.

Straub, K.L., Rainey, F.R. and Widdel, F. (1999) Rhodovulum iodosum sp. nov. and Rhodovulum robiginosum sp. nov., two new marine phototrophic ferrous-iron-oxidizing purple bacteria. Int. J. Syst. Bacteriol., 49, 729-735.

Strauss, H. (2003) Sulphur isotopes and the early Archean sulphur cycle. Precambrian Res., 126, 349-361.

Strauss, H., Des Marais, D.J., Hayes, J.M. and Summons, R.E. (1992) Concentrations of organic carbon and maturites and elemental compositions of kerogens. In: The Proterozoic Biosphere (Eds J.W. Schopf and C. Klein), pp. 95-99. Cambridge University Press, Cambridge.

Summons, R.E., Jahnke, L.L., Hope, J.M. and Logan, G.A. (1999) 2-Methylhopanoids as biomarkers for cyanobacterial oxygenic photosynthesis. Nature, $\mathbf{4 0 0}$, 554-557.

Tice, M.M. and Lowe, D.R. (2004) Photosynthetic microbial mats in the 3,416 Myr old ocean. Nature, 431, 549-552.

Trendall, A.F. (2002) The significance of iron-formation in the Precambrian stratigraphic record. Int. Assoc. Sedimentol. Spec. Publ., 33, 33-66.

Trendall, A.F. and Blockley, J.G. (1970) The iron formations of the Precambrian Hamersley Group, Western Australia; with special reference to the associated crocidolite. $W$. Austr. Geol. Surv. Bull., 119, 336.

Van Kranendonk, M.J. (2006) Volcanic degassing, hydrothermal circulation and the flourishing of early life on Earth: a review of the evidence from c. 3490-3240 Ma rocks of the Pilbara Supergroup, Pilbara Craton, Western Australia. Earth-Sci. Rev., 74, 197-240.

Vargas, M., Kashefi, K., Blunt-Harris, E.L. and Lovely, D.R. (1998) Microbiological evidence for Fe(III) reduction on early Earth. Nature, 395, 65-67.

Waldbauer, J.R., Newman, D.K. and Summons, R.E. (2011) Microaerobic steroid biosynthesis and the molecular fossil record of Archean life. Proc. Natl Acad. Sci. USA, 108, 13409-13414.

Walker, J.C.G. (1984) Suboxic diagenesis in banded iron formations. Nature, 309, 340-342.

Widdel, F., Schnell, S., Heising, S., Ehrenreich, A., Assmus, B. and Schink, B. (1993) Ferrous iron oxidation by anoxygenic phototrophic bacteria. Nature, 362, 834-836.

Woese, C.R. (1987) Bacterial evolution. Microbiol. Rev., 51, 221-271.

Wright, D.T. and Altermann, W. (2000) Microfacies development in Late Archaean stromatolites and oolites of 
1754 N. R. Posth et al.

the Campbellrand Subgroup, South Africa. In: Carbonate Platform Systems: Components and Interactions (Eds E. Insalco, P.W. Skelton and T.J. Palmer), Geol. Soc. London Spec. Publ., 178, 51-70.

Xiong, J. (2006) Photosynthesis: what color was its origin? Genome Biol., 7(12), 245.1-245.5.

Yamaguchi, K.E., Johnson, C.M., Beard, B.L. and Ohmoto, H. (2005) Biogeochemical cycling of iron in the Archean
Palaeoproterozoic Earth: constraints from iron isotope variations in sedimentary rocks from the Kaapvaal and Pilbara Cratons. Chem. Geol., 218, 135-169.

Manuscript received 6 December 2011; revision accepted 4 April 2013 